\title{
Basin-wide distributions of living carbon components and the inverted trophic pyramid of the central gyre of the North Atlantic Ocean, summer 1993
}

\author{
K. R. Buck ${ }^{1, *}$, F. P. Chavez ${ }^{1}$, L. Campbell ${ }^{2}$ \\ ${ }^{1}$ Monterey Bay Aquarium Research Institute, Box 628, Moss Landing, California 95039, USA \\ ${ }^{2}$ Department of Oceanography, SOEST, University of Hawaii, Honolulu, Hawaii 96822, USA
}

\begin{abstract}
Total living carbon biomass of microplankton, nanoplankton and picoplankton was estimated using a combination of dual beam flow cytometry and epifluorescence microscopy for surface samples along a basin-wide transect from $5^{\circ} \mathrm{S}$ to $61^{\circ} \mathrm{N}$ in the North Atlantic during the summer of 1993. We used constant per cell carbon estimates for the 4 groups of picoplankton (Prochlorococcus, Synechococcus, eukaryotic picophytoplankton and heterotrophic bacteria), and volume sensitive carbon estimates for the other groups in compiling the autotrophic and heterotrophic components. This yielded 2 regions where the autotrophic biomass was greater $(54 \%$ of total living carbon $)$ than the heterotrophic biomass, the tropical $\left(5^{\circ} \mathrm{S}\right.$ to $\left.24^{\circ} \mathrm{N}\right)$ and subarctic $\left(50^{\circ}\right.$ to $\left.61^{\circ} \mathrm{N}\right)$ regions. In the subtropical region $\left(25^{\circ}\right.$ to $45^{\circ} \mathrm{N}$ ), however, heterotrophic biomass outweighed (59\% of total living carbon) autotrophic biomass. Although this phenomenon has previously been reported from this and other oligotrophic areas, our findings indicate that the degree of heterotrophy has been overestimated by reliance upon chlorophyll as a surrogate for autotrophic biomass. The phytoplankton carbon to chlorophyll ratios we generate covary with chlorophyll with the highest ratios found in the most oligotrophic regions. Application of a constant carbon to chlorophyll ratio would therefore underestimate the contribution of autotrophs most in the oligotrophic regions. Nano- and microplankton contribute $40 \%$ of the total living carbon biomass of the subtropical region. Bacterial abundances covaried with phytoplankton biomass across all the trophic regions we sampled, however the regression we generated for this relationship from the basin-wide survey predicts significantly higher bacterial abundances for given chlorophyll concentrations than earlier reports suggested.
\end{abstract}

KEY WORDS: Living carbon - North Atlantic

\section{INTRODUCTION}

An inverted trophic pyramid (i.e. the biomass of the heterotrophic component equal to or exceeding the biomass of autotrophic components) in the microbial food web of oligotrophic regions of the open ocean has been a persistent finding of all studies that have addressed this issue (Dortch \& Packard 1989, Fuhrman et al. 1989, Cho \& Azam 1990, Herndl 1991, Li et al. 1992, 1993). The proportion of the total living bio-

•E-mail: buku@mbari.org mass attributable to heterotrophs ranges from 0.5 to 0.83. Acceptance of this phenomenon over large spatial and temporal scales challenges current understanding of the coupling of DOC production by phytoplankton and subsequent uptake by heterotrophic bacteria. Low heterotrophic bacterial growth rates coupled with either high DOM release by the phytoplankton or the import of DOM from other regions is the scenario most likely to support such a biomass imbalance (Fuhrman 1992).

Previous investigators have used epifluorescence microscopy, flow cytometry, chlorophyll concentrations and chlorophyll to protein ratios to estimate the 
biomass comprising the autotrophic and heterotrophic components. Relying on epifluorescence microscopy to estimate the biomass of heterotrophic bacteria does not discriminate Prochlorococcus as an autotroph and consequently overestimates the abundance of bacteria (Campbell et al. 1994). Flow cytometry is capable of enumerating Prochlorococcus when the high sensitivity protocol (Olson et al. 1990) is used, however, this particular technique has not been employed in any of the studies looking at the biomass partitioning in the oligotrophic regions. In some cases carbon to chlorophyll ratios have also been used to estimate the phytoplankton component of total living carbon, however this approach is replete with potential problems (Banse 1977). Using several of the published carbon to chlorophyll ratios, Li et al. (1992) demonstrated a 3 fold variation in the degree of heterotrophy at their study site in the Sargasso Sea. When carbon to chlorophyll ratios are used to estimate the biomass of the autotrophs, the heterotrophic component is still estimated using epifluorescence microscopy with the attendant overestimation of the heterotrophic bacterial biomass when Prochlorococcus is abundant. Although some studies may have overestimated the abundance of heterotrophic bacteria, some studies have ignored the contribution of heterotrophic protists (Cho \& Azam 1990) or have used an indirect approach to calculate the magnitude of this heterotrophic component (Campbell et al. 1994). With the exception of chlorophyll to protein ratios, all the protocols used to estimate total living carbon in oligotrophic regions have potentially underestimated the autotrophic biomass and overestimated the heterotrophic bacterial biomass. Use of dual beam flow cytometry and the Hoechst fluorochrome (Monger \& Landry 1993) allows for the simultaneous enumeration of Prochlorococccus and heterotrophic bacteria, avoiding some of the potential problems associated with earlier studies. Campbell et al. (1994), using this protocol, derived a mean ratio of heterotrophic to total living carbon of 0.45 for the subtropical Pacific at the Hawaii Ocean Time (HOT) series station.

During a basin-wide cruise across the North Atlantic during the summer of 1993 we were able to directly estimate the biomass of heterotrophic bacteria, autotrophic picoplankton and the autotrophic and heterotrophic components of the nano- and microplankton using a combination of high sensitivity dual beam flow cytometry and epifluorescence microscopy. It was our expectation that the application of these techniques to water samples from the central gyre would result in autotrophic domination of the microbial food web biomass. Contrary to our expectations however, our results confirmed earlier reports that the proportion of the total living biomass attributable to heterotrophs exceeds 0.50 for the region from $26^{\circ}$ to $45^{\circ} \mathrm{N}$. The pro- portion of total living biomass attributable to heterotrophs in our study however, was markedly lower than in previous reports. Here we present the distribution of the pico-, nano-, and microplankton components of tatal living biomass in the North Atlantic and compare our results with earlier studies to examine the relationship of autotrophic to heterotrophic biomass.

\section{MATERIALS AND METHODS}

The transect from $5^{\circ} \mathrm{S}$ to $61^{\circ} \mathrm{N}$ in the Atlantic (Fig. 1) was sampled from 7 July to 28 August 1993 . The first leg was broken off at $14^{\circ} \mathrm{N}$ on 17 July due to shiprelated mechanical difficulties. Additional surface samples were then taken during the unplanned passage to Madeira which followed. The transect was continued from $34^{\circ} \mathrm{N}$ southward on 3 August, sampling the even numbered latitudes until $15^{\circ} \mathrm{N}$, after which we sampled the odd numbered latitudes as we steamed north again. Thus, although every station in this section was occupied, it was not done synoptically.

Flow cytometry (FC) samples from the euphotic zone were taken from acid cleaned Go-flo bottles deployed on Kevlar line at just below the surface or at the surface and $50,30,15,5$ and $1 \%$ incident light penetration depths (profiles). Depths below the euphotic zone (usually 100,150 and $200 \mathrm{~m}$ ) were sampled with Niskin bottles and a rosette. Profiles were obtained at $5^{\circ}$ lati-

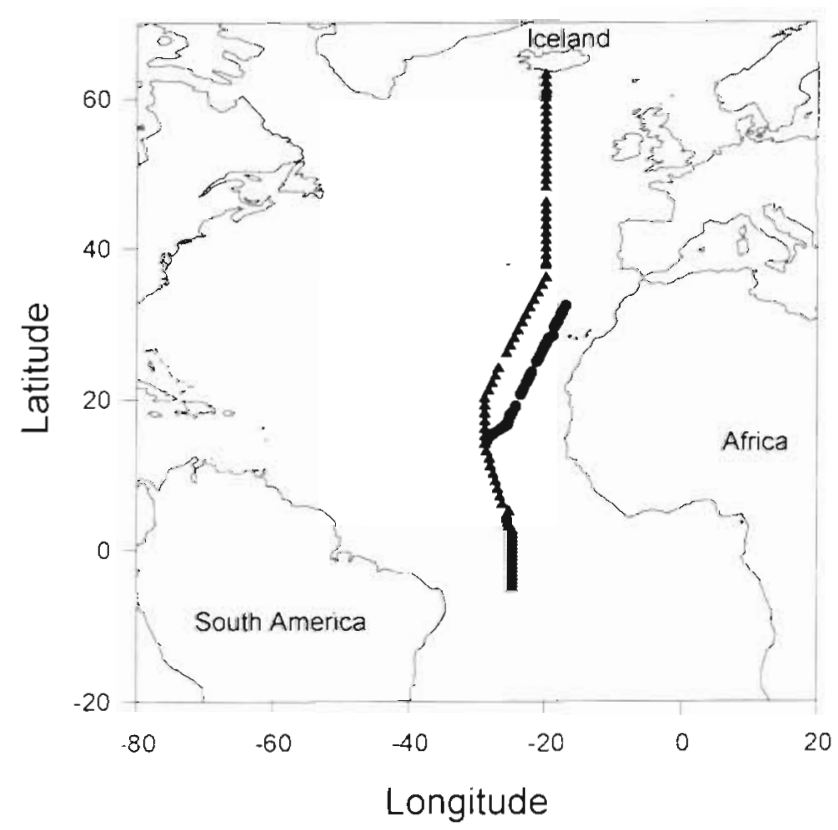

Fig. 1. Locations of the stations occupied in the eastern North Atlantic $\left(5^{\circ} \mathrm{S}\right.$ to $\left.61^{\circ} \mathrm{N}\right)$, July to August 1993. (a) Primary stations; $(\bullet$ surface samples taken during an unplanned transit to Madeira 
tudinal increments $(\mathrm{n}=14)$. While surface samples were taken at almost every degree of latitude $(n=51)$, coverage at the northern end of the transect had less resolution (Fig. 1). During the first transit to Madeira (Fig. 1), samples were taken approximately every $2 \mathrm{~h}$ (approximately 25 nautical miles) from the underway sampling system which samples at about $5 \mathrm{~m}$. All FC samples were dispensed into $1.8 \mathrm{ml}$ cryovials, preserved with paraformaldehyde (final conc. $=0.2 \%$ ) and stored in liquid nitrogen. Samples were shipped, on dry ice, to the University of Hawaii, Dept of Oceanography, where they were analyzed for picoplankton abundance and red fluorescence per cell according to the protocols outlined in Monger \& Landry (1993) and Campbell et al. (1994). The particular FC configuration used in this analysis does not provide reliable estimates of cell volume for heterotrophic bacteria. FC analyses of eukaryotic picophytoplankton and Synechococcus were done on the same volume of water $(50 \mu \mathrm{l})$ used for Prochlorococcus and heterotrophic bacterial analysis. FC cell counts ranged from 0 to 247 $($ mean $=37)$ and 0 to $1218($ mean $=212)$ for eukaryotic picophytoplankton and Synechococcus respectively. A comparison of the estimates of Synechococcus and eukaryotic picophytoplankton generated from FC and epifluorescence microscopy (EFM) reveals close correspondence between the 2 estimates (Fig. 2) and justifies the use of the flow cytometry estimates of Synechococcus and eukaryotic picophytoplankton. Precision for estimates of Prochlorococcus and heterotrophic bacteria using FC is better than 5\% (Monger \& Landry 1993)

Samples for epifluorescence microscopy were taken from the surface Go-flo bottle and prepared and enumerated following the protocol outlined in Buck et al. (1992). An important difference between this protocol and that used previously (Chavez et al. 1991) was that most of the samples were counted aboard ship on the same day the filters were prepared. In addition, large and rare organisms such as the epizooic heterotrophic flagellate Solenicola setigera and the diazotroph $T_{r i-}$ chodesmium were enumerated and measured in the laboratory on $5 \mu \mathrm{m}$ pore sized polycarbonate filters through which 100 to $200 \mathrm{ml}$ was filtered. The carbon conversions used are those outlined in Campbell et al. (1994) (53 fg C cell ${ }^{-1}$ for Prochlorococcus, $250 \mathrm{fg} \mathrm{C}$ cell $^{-1}$ for Synechococcus, $2100 \mathrm{fg} \mathrm{C} \mathrm{cell}^{-1}$ for picoeukaryotes, and $20 \mathrm{fg} \mathrm{C} \mathrm{cell}^{-1}$ for heterotrophic bacteria) with the exception of the nano-/microphytoplankton and heterotrophs where we used the Eppley et al. (1970) conversion $\left(\log _{10} \mathrm{C}=0.76 \log _{10}\right.$ Volume -0.29 for diatoms and $\log _{10} \mathrm{C}=0.94 \log _{10}$ Volume -0.6 for other nano-/microphytoplankton and heterotrophs) and Trichodesmium for which we used Karl et al. (1992) $\left(6.4 \times 10^{-2} \mathrm{~g} \mathrm{C} \mathrm{cm}^{-3}\right)$. Chlorophyll was deter-

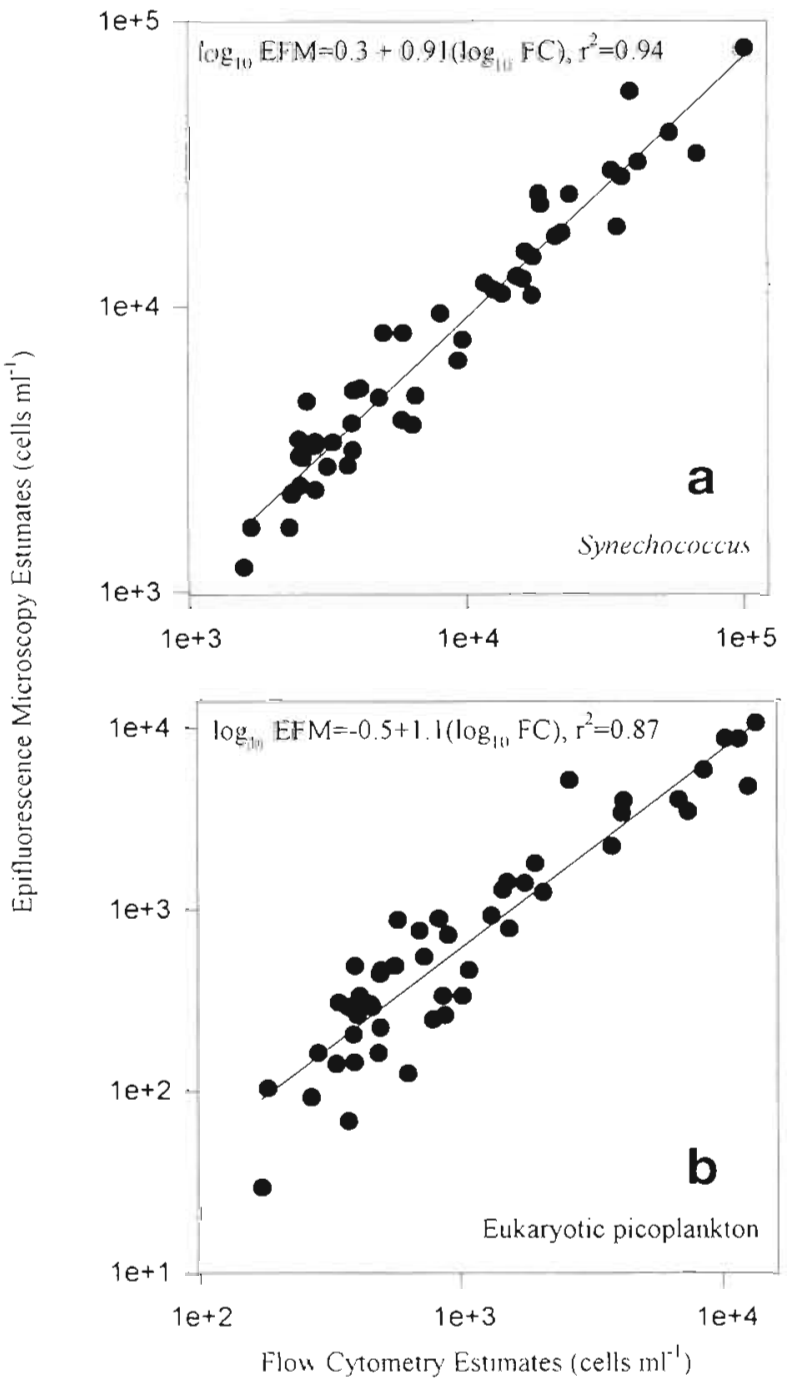

Fig. 2. Comparison of abundance estimates for (a) Synechococcus and (b) eukaryotic picophytoplankton generated by epifluorescence microscopy and flow cytometry for 50 surface samples taken from the North Atlantic, July to August 1993

mined by the fluorometric technique of Holm-Hansen et al. (1965).

In some cases data were $\log _{10}$ transformed to meet assumptions of regression analysis (homogeneity of variance). Back-transformation of predicted values to arithmetic units results in a systematic bias that can be eliminated by application of a correction factor (Baskerville 1972, Sprugel 1983). The correction factor (CF) was calculated as: $\mathrm{CF}=\exp \left(2.303 \mathrm{RSE}^{2} / 2\right)$ where RSE is the residual standard error of the regression equation, and 2.303 is the conversion from $\log _{10}$ to $\log _{e}$. Linear model theory was used to generate regressions for our data and we limit our comparisons to other studies also using linear model theory. 


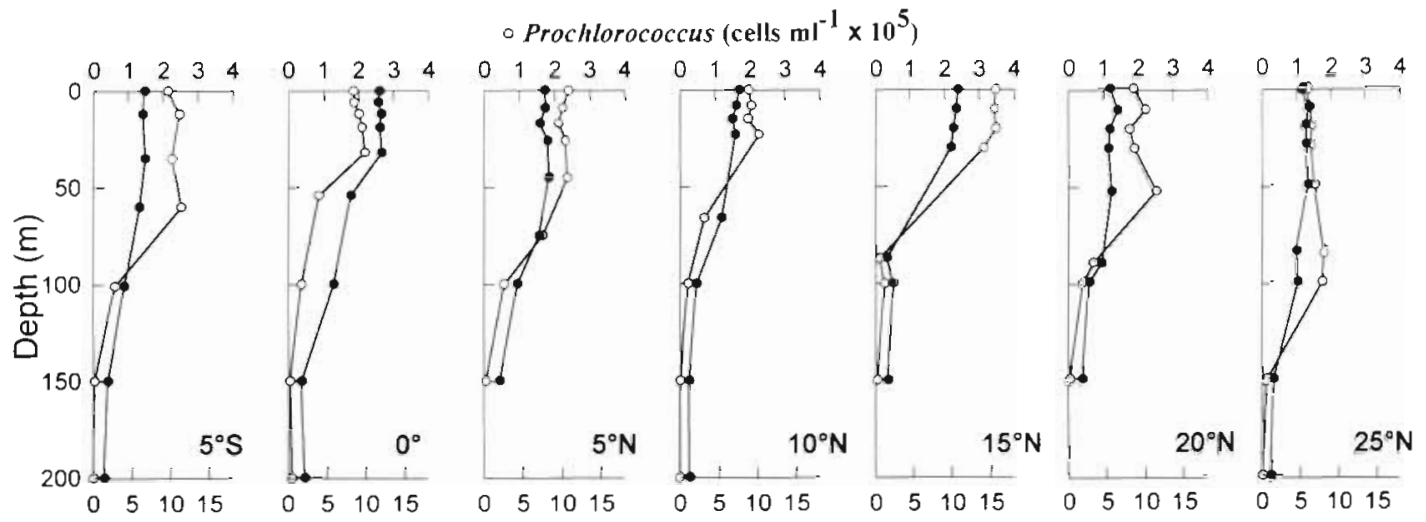

- Heterotrophic bacteria (cells $\mathrm{ml}^{-1} \times 10^{5}$ )

- Prochlorococcus (cells ml ${ }^{-1} \times 10^{5}$ )

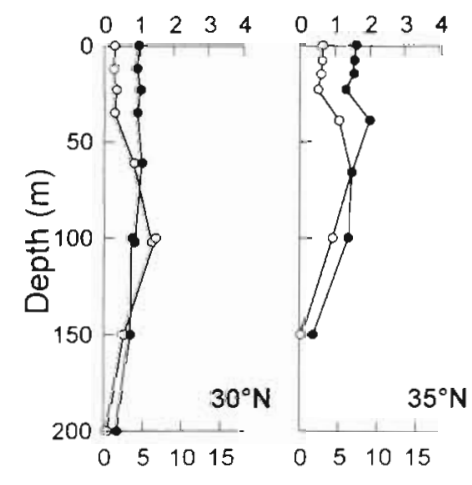

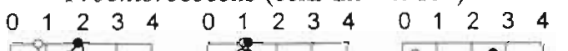
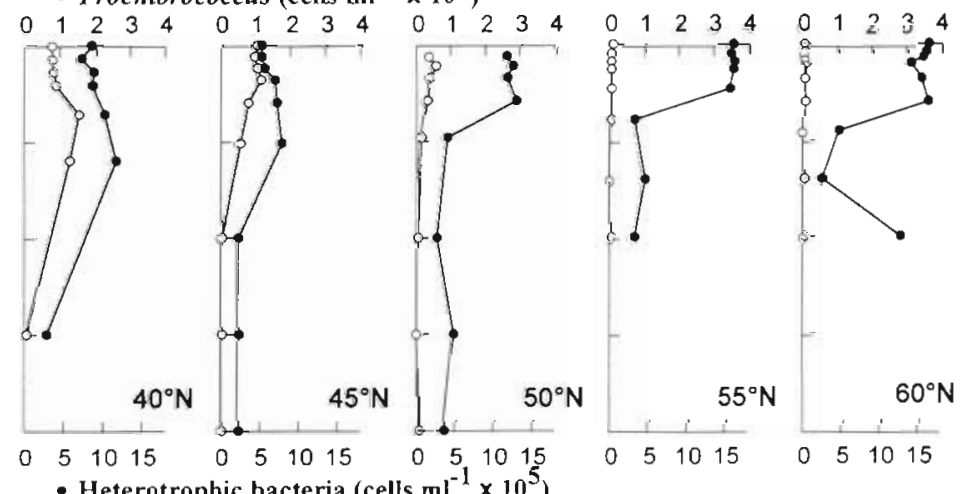

- Heterotrophic bacteria (cells $\mathrm{ml}^{-1} \times 10^{5}$ )

- Synechococcus (cells mI $\mathrm{m}^{-1} \times 10^{4}$ )
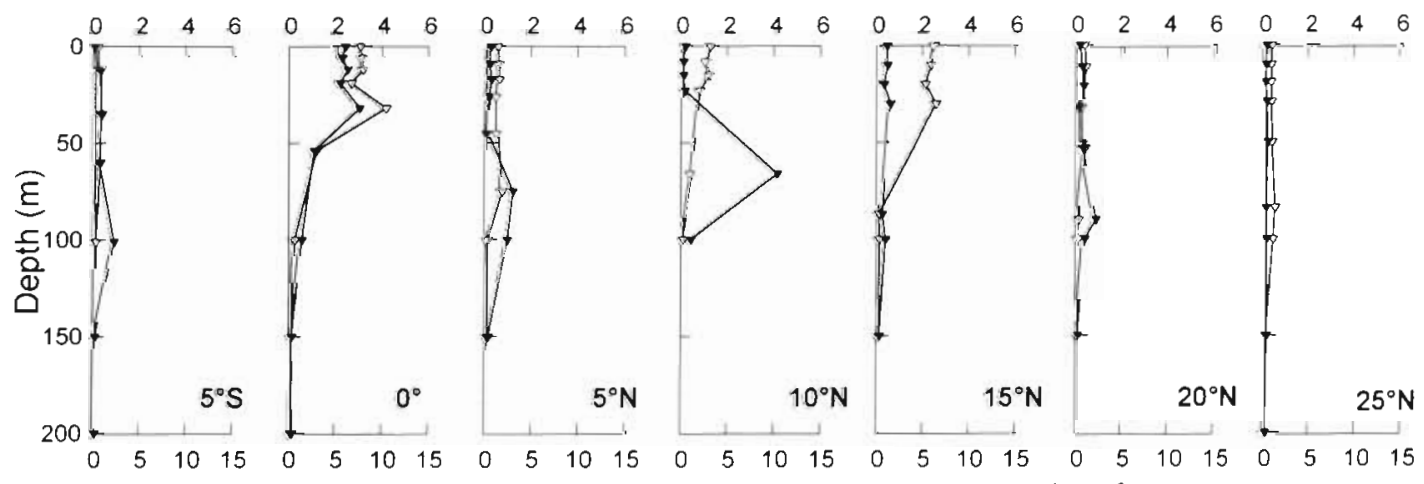

- Eukaryotic picophytoplankton (cells $\mathrm{ml}^{-1} \times 10^{3}$ )

$\checkmark$ Synechococcus (cells ml ${ }^{-1} \times 10^{4}$ )
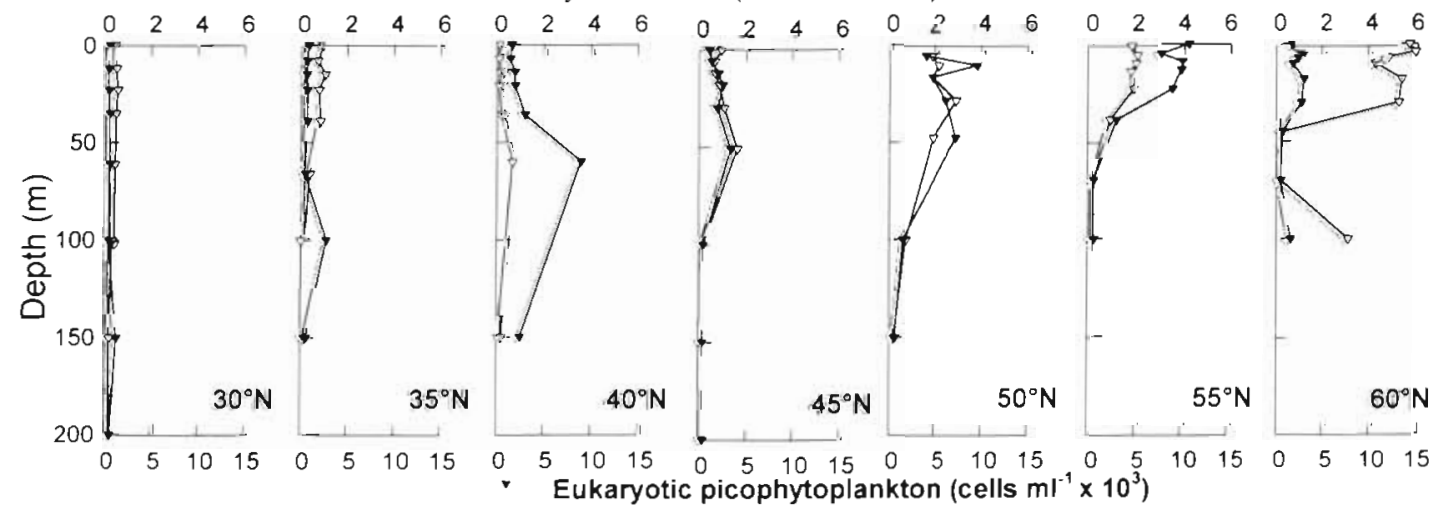

Fig. 3. Vertical profiles of Prochlorococcus, heterotrophic bacteria, Synechococcus and eukaryotic picophytoplankton abundance (cells $\mathrm{ml}^{-1}$ ) at 14 stations in the North Atlantic, July to August 1993 


\section{RESULTS}

To simplify the description of the distributions, we have divided the $5^{\circ} \mathrm{S}$ to $61^{\circ} \mathrm{N}$ transect into 3 regions: the tropical region from $5^{\circ} \mathrm{S}$ to $24^{\circ} \mathrm{N}$, the subtropical region from $25^{\circ}$ to $45^{\circ} \mathrm{N}$ and the subarctic region from $50^{\circ}$ to $61^{\circ} \mathrm{N}$. These boundaries correspond well with the depth of the nitracline (data not shown), the boundaries of the true tropical zone (Le Bouteiller et al. 1992) and major changes in the distribution of Prochlorococcus (Fig. 3) throughout the water column.

\section{Picoplankton}

Total picoplankton biomass ranged from 11 to $99 \mu \mathrm{g} \mathrm{C} \mathrm{l}^{-1}$. Highest mean ( $\pm \mathrm{SD}$ ) biomass $\left(48 \pm 8 \mathrm{\mu g} \mathrm{C}^{-1}\right)$ occurred in the subarctic and lowest $\left(18 \pm 7 \mu \mathrm{g} \mathrm{C}^{-1}\right)$ in the subtropical region while picoplankton in the tropical region averaged $33 \pm 15 \mathrm{\mu g} \mathrm{Cl}^{-1}$.

Prochlorococcus. North of $45^{\circ} \mathrm{N}$ there was little Prochlorococcus biomass at either the surface or at depth in the water column (Figs. 3 to 6 , Tables 1 to 4 !. This subarctic region is bounded on the south at the surface by the $18^{\circ} \mathrm{C}$ isotherm (Fig. 5). At the northernmost profile station $\left(60^{\circ} \mathrm{N}\right)$, where the surface temperature was $10.2^{\circ} \mathrm{C}$ (Fig. 5), the $F C$ recorded a low surface abundance of Prochlorococcus $\left(>10^{3}\right.$ cells $\mathrm{ml}^{-1}$ ) and a maximum concentration of $8 \times 10^{3}$ cells $\mathrm{ml}^{-1}$ was found at $10 \mathrm{~m}$ (Fig. 3). The counts for this station ranged from 29 to 172 and, with a precision on the order of 5 to $10 \%$ for abundances of this magnitude, we assume these are valid estimates.

The subtropical region from $45^{\circ}$ to $25^{\circ} \mathrm{N}$, which approximates the central gyre, is characterized by low Prochlorococcus surface abundances but deep subsurface maxima (Figs. $3 \& 5$, Tables $1,2 \& 4$ ). The subsurface maxima at the stations in the subtropical region

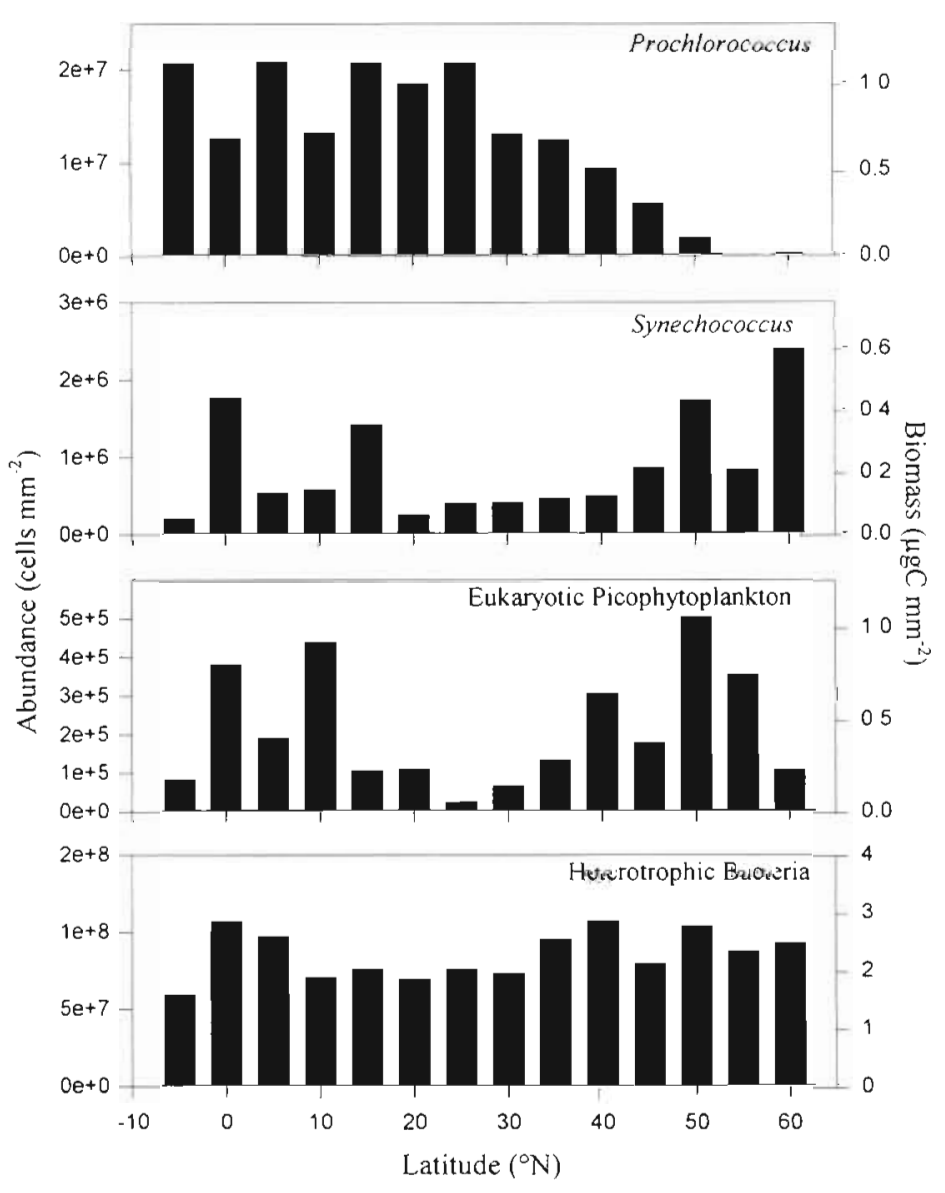

Fig. 4. Integrated abundance (cells $\mathrm{mm}^{-2}$ ) and biomass ( $\mu \mathrm{g} \mathrm{C} \mathrm{mm} \mathrm{m}^{-2}$ ) of Prochlorococcus, Synechococcus, eukaryotic picophytoplankton and heterotrophic bacteria, in the upper water column at 14 stations in the North Atlantic, July to August 1993

range in abundance from 1.1 to $1.8 \times 10^{5}{\text { cells } \mathrm{ml}^{-1}}^{-1}$ (Fig. 3, Table 2). The mean depth of the maxima is shallower than the mean depth of the Deep Chlorophyll Maximum (DCM) (Table 2).

The tropical region had high surface abundances $\left(2.3 \times 10^{5}\right.$ cells $\left.\mathrm{ml}^{-1}\right)$ distributed throughout the upper water column (Figs. $3 \& 5$, Table 1 ). In fact the surface samples taken at $1^{\circ}, 20.6^{\circ}, 20.9^{\circ}$ and $22.5^{\circ} \mathrm{N}$ had abun-

Table 1. Mean $( \pm \mathrm{SD})$ abundance $\left(\times 10^{3}\right.$ cells $\left.\mathrm{ml}^{-1}\right)$ of picoplankton, analyzed with flow cytometry, from the surface $(\mathrm{N}=53)$ and at depth where vertical profiles were done $(\mathrm{N}=14)$ from the North Atlantic, July-August 1993, and the percent contribution of Prochlorococcus to small prokaryotes (Prochlorococcus + heterotrophic bacteria)

\begin{tabular}{|lccccc|}
\hline & Prochlorococcus & Synechococcus & $\begin{array}{c}\text { Eukaryotic } \\
\text { picophytoplankton }\end{array}$ & $\begin{array}{c}\text { Heterotrophic } \\
\text { bacteria }\end{array}$ & $\begin{array}{c}\% \\
\text { Prochlorococcus }\end{array}$ \\
\hline $5^{\circ} \mathrm{S}-24^{\circ} \mathrm{N}(\mathrm{N}=70)$ & $183 \pm 111$ & $9.3 \pm 13$ & $1.2 \pm 1.9$ & $659 \pm 342$ & $0.20 \pm 0.08$ \\
$25^{\circ} \mathrm{N}-45^{\circ} \mathrm{N}(\mathrm{N}=54)$ & $73 \pm 54$ & $3.6 \pm 3.1$ & $0.6 \pm 1.1$ & $517 \pm 246$ & $0.12 \pm 0.07$ \\
$50^{\circ} \mathrm{N}-61^{\circ} \mathrm{N}(\mathrm{N}=33)$ & $6.8 \pm 12.8$ & $21.5 \pm 17.9$ & $3.9 \pm 3.5$ & $1068 \pm 553$ & $0.01 \pm 0.01$ \\
\hline
\end{tabular}




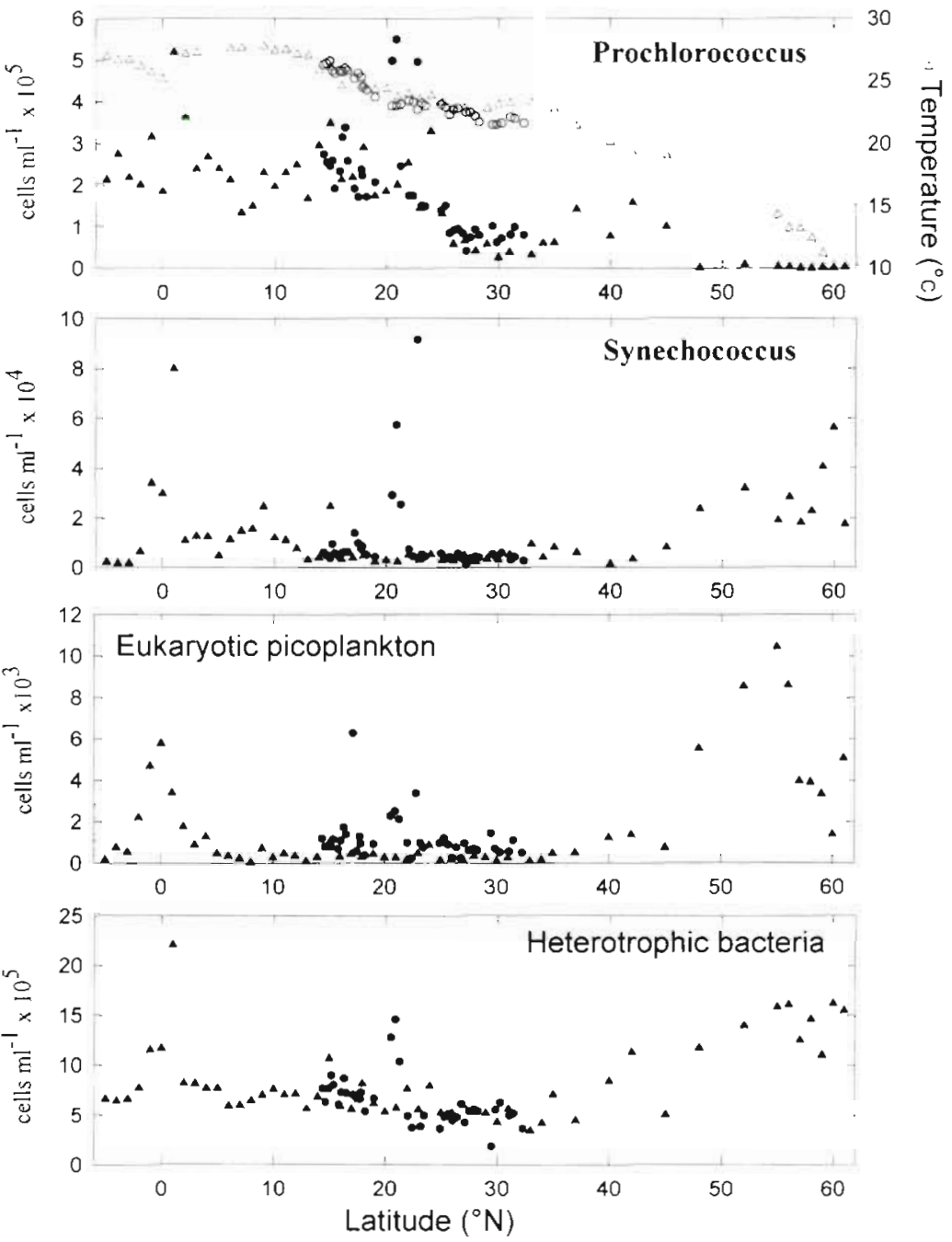

Fig. 5. Surface abundance (filled symbols, cells $\mathrm{ml}^{-1}$ ) of Prochlorococcus, Synechococcus, eukaryotic picophytoplankton and heterotrophic bacteria and temperature (open symbols, ${ }^{\circ} \mathrm{C}$ ) from the North Atlantic, July to August 1993. Circles represent samples taken from the auxiliary transit to Madeira (see Fig. 1)

dances in excess of $4.9 \times 10^{5}$ cells $\mathrm{ml}^{-1}$, the highest reported for oceanic samples (Fig. 5). The maxima of the profiles taken in the tropical region were also located shallower than the mean DCM depth (Fig. 3, Table 2).

Integrated abundances of Prochlorococcus, however, do not break into the same geographical regions as the discrete abundances or profiles. Owing, in part, to increasing depth of the euphotic zone in the subtropical region, several of the stations there have integrated abundances similar to those of the tropical region (Fig. 4, Table 3)

Synechococcus. Synechococcus abundances recorded in this study were low throughout the subtropical region but high at the equator, the 3 stations on the underway transect near $20^{\circ} \mathrm{N}$, and at the northern extreme of the transect (Fig. 5). Vertical profiles displayed no consistent trend with respect to depth (Fig. 3, Table 2). Integrated abundances were highest in the tropical and subarctic regions (Fig. 4, Table 3)

Eukaryotic picophytoplankton. Surface eukaryatic picophytoplankton exhibited high variability along the transect (Fig. 5). High abundances were observed in the equatorial region $\left(2^{\circ} \mathrm{S}\right.$ to $1^{\circ} \mathrm{N}$ ) and north of $51^{\circ} \mathrm{N}$. The remaining segment of the transect was characterized by low surface abundances. The presence of a distinct subsurface maximum characterized the vertical profiles (Fig. 3, Table 2). Integrated abundances were highest in the tropical and subarctic regions (Fig. 4 , Table 3 ).

Heterotrophic bacteria. Heterotrophic bacterial surface abundances were high at the equator and at the northern end of the transect with uniform abundances characterizing most of the transect (Fig. 5). The coefficient of variation for heterotrophic bacterial abundances was the lowest of any picoplankton group (Tables 1 \& 4). This lack of variability is reflected in the integrated abundances as well (Fig. 4, Table 3). Abundance in the mixed layer was uniformly high, decreasing with depth to low abundances by $200 \mathrm{~m}$ (Fig. 3).

Heterotrophic bacteria always outnumbered Prochlorococcus. However, due to the disparity in the cellular carbon concentration, the biomass balance between these 2 prokaryotes was close to unity for large regions of the North Atlantic (Fig. 4, Tables $3 \& 4$ ). The mean $( \pm \mathrm{SD})$ ratio of Prochlorococcus to total prokaryote (Prochlorococcus + heterotrophic bacteria) biomass at the surface was $0.45 \pm 0.05$ for the tropical region. The mean ratio $( \pm \mathrm{SD})$ for the upper $100 \mathrm{~m}$ was $0.39 \pm 0.10 \mathrm{at}$ those stations where we did profiles in the same region, reflecting the uniformity of distribution of both these prokaryotes in the upper water column. The subtropical mean $( \pm \mathrm{SD})$ Prochlorococcus biomass to total prokaryote biomass ratio is $0.25 \pm 0.09$ for the surface and $0.27 \pm 0.13$ for the upper $100 \mathrm{~m}$ (Table 4 ). Although Prochlorococcus and heterotrophic bacteria were the 2 most abundant picoplankton, the integrated biomass of eukaryotic picophytoplankton often exceeded that of Prochlorococcus (Fig. 4, Table 3), particularly at stations north of $40^{\circ} \mathrm{N}$ 
Table 2. Depth $(\mathrm{m})$ of the chlorophyll maximum (DCM), maximum cell abundance $\left(\times 10^{3} \mathrm{ml}^{-1}\right.$ ) (Abund) and depth of the maximum concentration $(z)$ of Prochlorococcus, Synechococcus, eukaryotic picophytoplankton, and heterotrophic bacteria at the 14 stations where depth profiles were done in the North Atlantic, July-August 1993

\begin{tabular}{|c|c|c|c|c|c|c|c|c|c|}
\hline \multirow[t]{2}{*}{ Latitude } & \multirow[t]{2}{*}{ DCM } & \multicolumn{2}{|c|}{ Prochlorococcus } & \multicolumn{2}{|c|}{ Synechococcus } & \multicolumn{2}{|c|}{$\begin{array}{c}\text { Eukaryotic } \\
\text { picophytoplankton }\end{array}$} & \multicolumn{2}{|c|}{$\begin{array}{c}\text { Heterotrophic } \\
\text { bacteria }\end{array}$} \\
\hline & & Abund & $z$ & Abund & $z$ & Abund & $z$ & Abund & $z$ \\
\hline $5^{\circ} \mathrm{S}$ & 100 & 252 & 60 & 2.4 & 12 & 0.4 & 12 & 663 & 35 \\
\hline 0 & 32 & 217 & 32 & 40.8 & 32 & 7.4 & 32 & 1191 & 32 \\
\hline $5^{\circ} \mathrm{N}$ & 80 & 240 & 0 & 6.6 & 75 & 2.8 & 75 & 825 & 45 \\
\hline $10^{\circ} \mathrm{N}$ & 66 & 225 & 23 & 11.7 & 15 & 10.2 & 66 & 760 & 0 \\
\hline $15^{\circ} \mathrm{N}$ & 45 & 349 & 20 & 25.1 & 30 & 14.6 & 52 & 1107 & 52 \\
\hline $20^{\circ} \mathrm{N}$ & 90 & 251 & 53 & 3.5 & 11 & 2.0 & 90 & 630 & 11 \\
\hline $25^{\circ} \mathrm{N}$ & 100 & 181 & 84 & 4.1 & 84 & 0.3 & 50 & 598 & 10 \\
\hline $30^{\circ} \mathrm{N}$ & 150 & 144 & 100 & 3.9 & 23 & 0.1 & 61 & 474 & 61 \\
\hline $35^{\circ} \mathrm{N}$ & 100 & 144 & 66 & 9.0 & 15 & 2.4 & 100 & 880 & 39 \\
\hline $40^{\circ} \mathrm{N}$ & 70 & 150 & 36 & 8.6 & 60 & 6.6 & 60 & 1149 & 60 \\
\hline $45^{\circ} \mathrm{N}$ & 51 & 111 & 18 & 15.0 & 51 & 3.0 & 51 & 762 & 51 \\
\hline $50^{\circ} \mathrm{N}$ & 29 & 53 & 11 & 27.5 & 29 & 9.1 & 11 & 1280 & 29 \\
\hline $55^{\circ} \mathrm{N}$ & 20 & 4.5 & 0 & 31.8 & 0 & 10.4 & 0 & 1599 & 9 \\
\hline $60^{\circ} \mathrm{N}$ & 0 & 8.0 & 10 & 59.0 & 4 & 2.6 & 4 & 1621 & 0 \\
\hline $\begin{array}{l}\text { Mean } \pm \mathrm{SD} \\
\left(5^{\circ} \mathrm{S}-20^{\circ} \mathrm{N}\right)\end{array}$ & $69 \pm 26$ & $256 \pm 49$ & $31 \pm 22$ & $15 \pm 15$ & $29 \pm 24$ & $6 \pm 5$ & $55 \pm 29$ & $863 \pm 233$ & $29 \pm 20$ \\
\hline $\begin{array}{l}\text { Mean } \pm S D \\
\left(25^{\circ} \mathrm{N}-45^{\circ} \mathrm{N}\right)\end{array}$ & $94 \pm 38$ & $146 \pm 25$ & $61 \pm 34$ & $8 \pm 5$ & $47 \pm 28$ & $2 \pm 3$ & $47 \pm 28$ & $772 \pm 261$ & $44 \pm 21$ \\
\hline $\begin{array}{l}\text { Mean } \pm S D \\
\left(50^{\circ} \mathrm{N}-60^{\circ} \mathrm{N}\right)\end{array}$ & $16 \pm 15$ & $22 \pm 27$ & $7 \pm 6$ & $39 \pm 17$ & $11 \pm 16$ & $7 \pm 4$ & $5 \pm 6$ & $1500 \pm 190$ & $13 \pm 15$ \\
\hline
\end{tabular}

Picoplankton
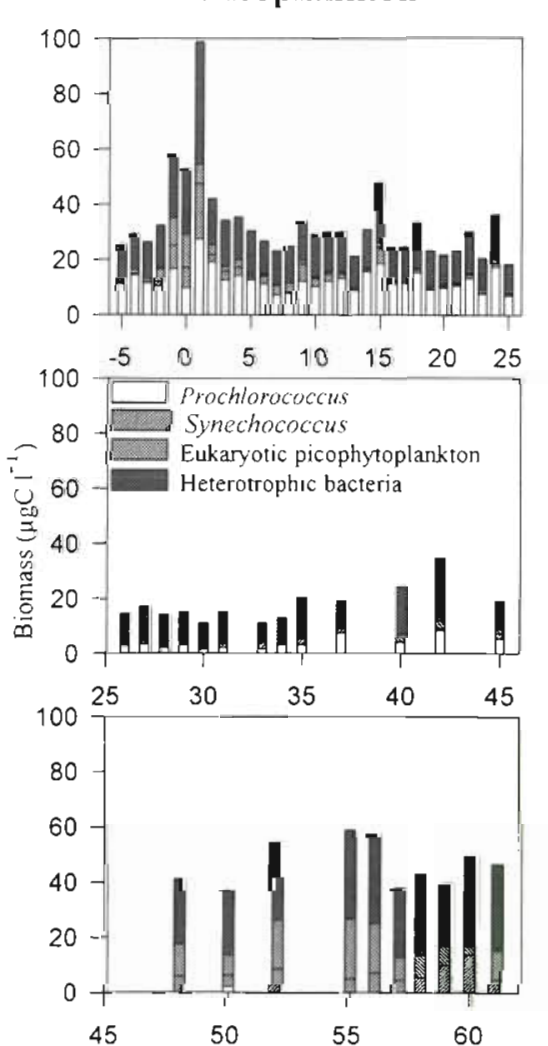

Nano/microplankton
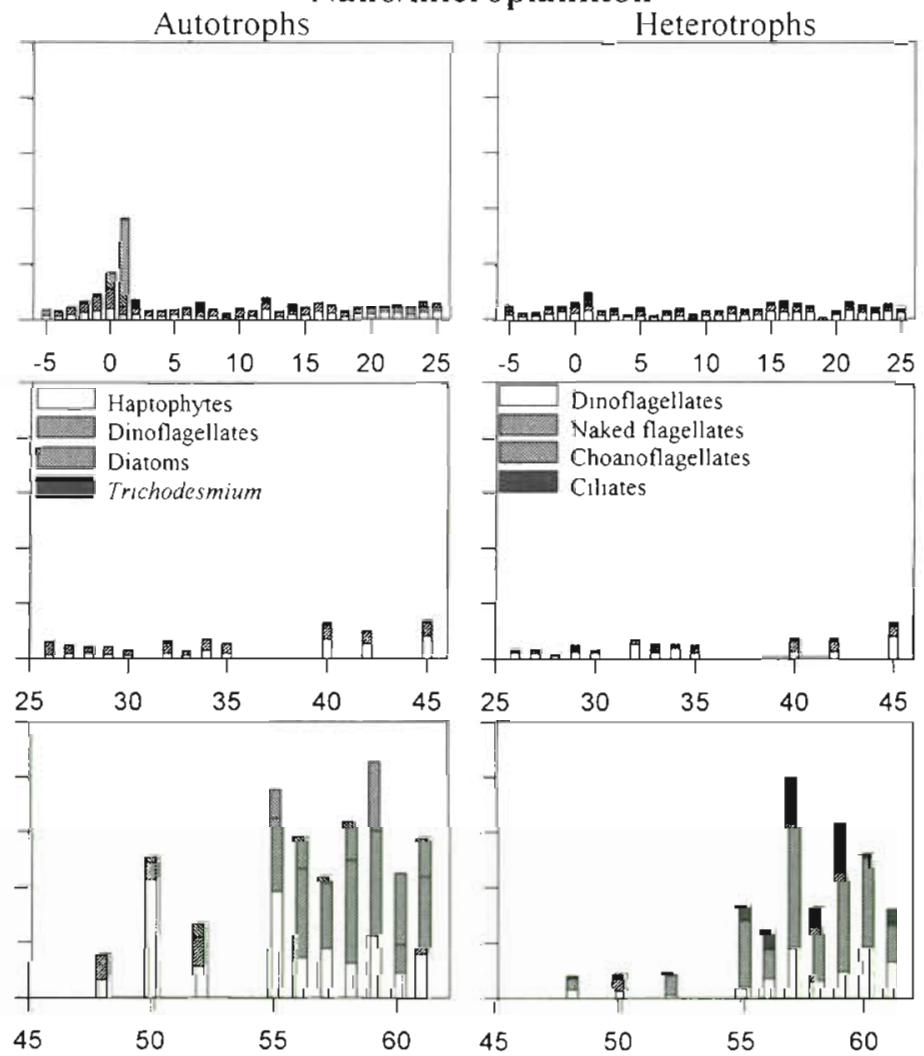

Fig. 6. Biomass ( $\mu \mathrm{g} \mathrm{Cl}^{-1}$ ) of some of the major components of picoplankton, autotrophic nano-/microplankton and heterotrophic nano-/microplankton from the surface at 51 stations occupied in the North Atlantic, July to August 1993. Top row: tropical region; middle row: subtropical region; bottom row: subarctic region 


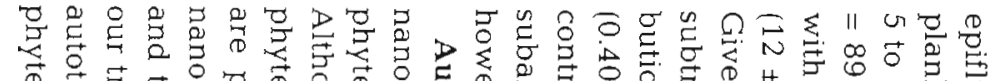

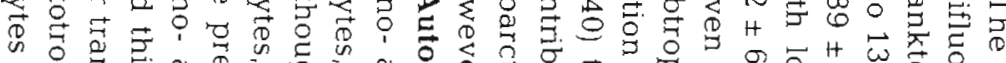

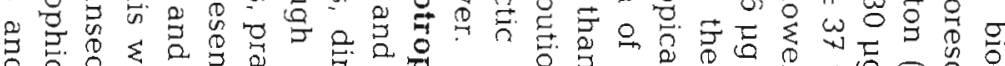

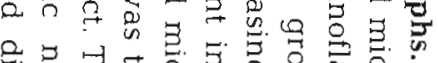

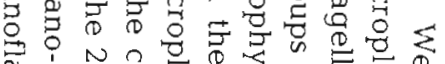

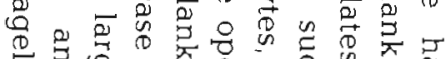

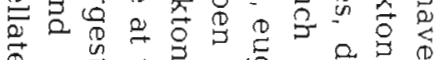

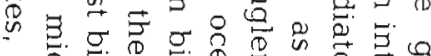

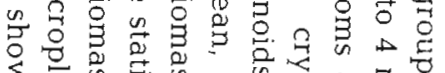

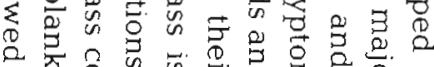

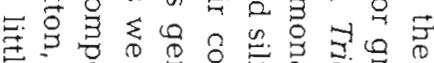

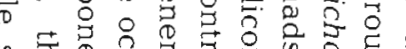

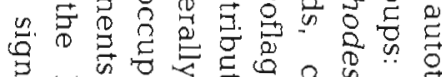

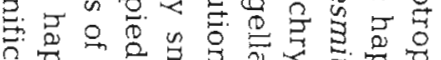

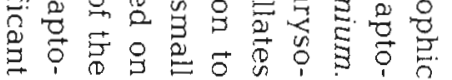

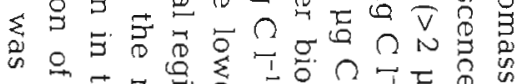
在者

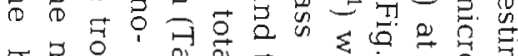
E.

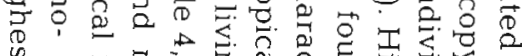

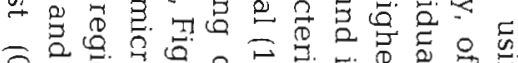

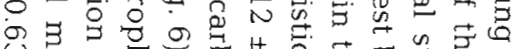

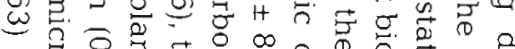

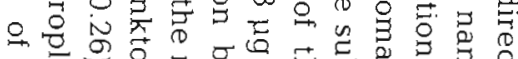

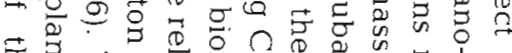

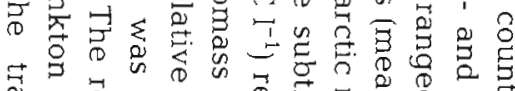

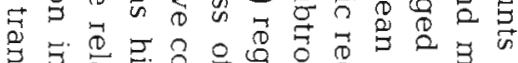

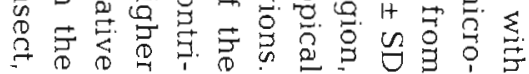

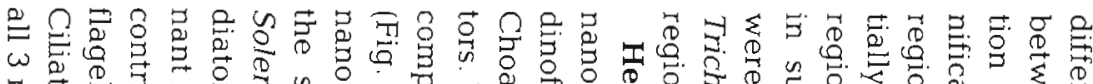

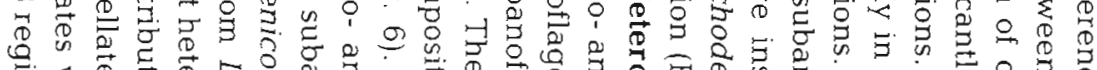

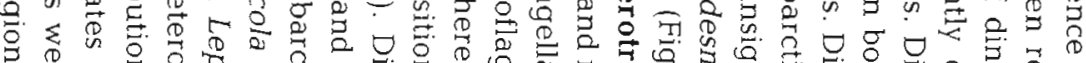

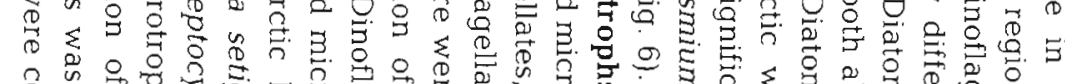

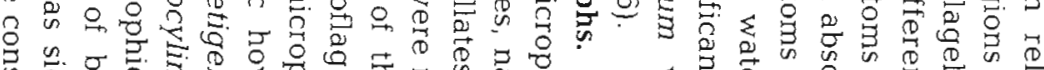

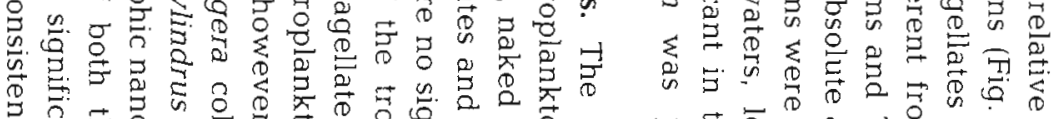

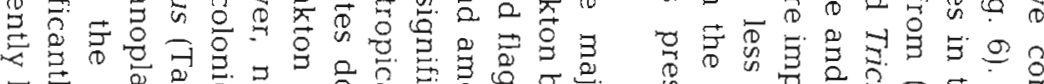

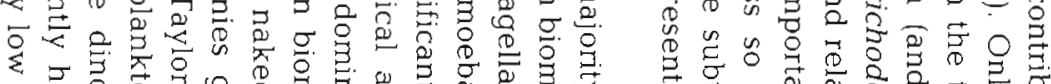

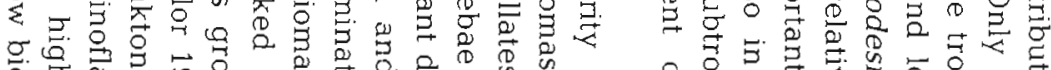

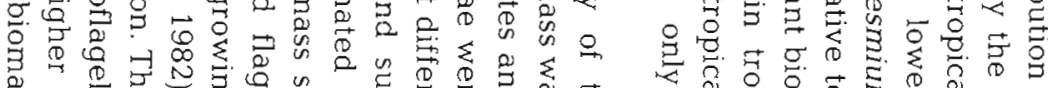

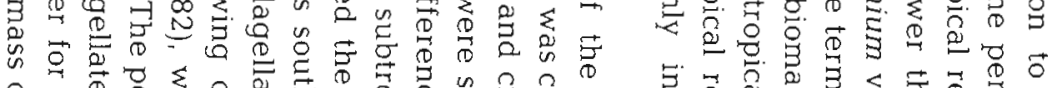

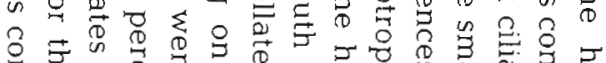

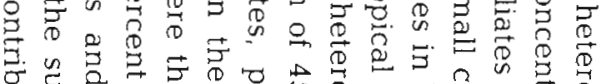

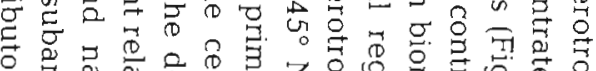

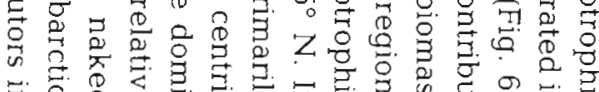

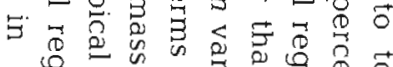

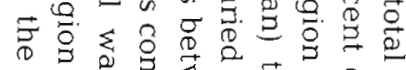

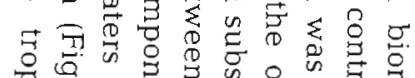

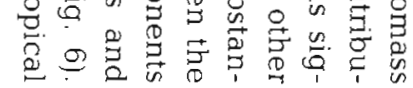

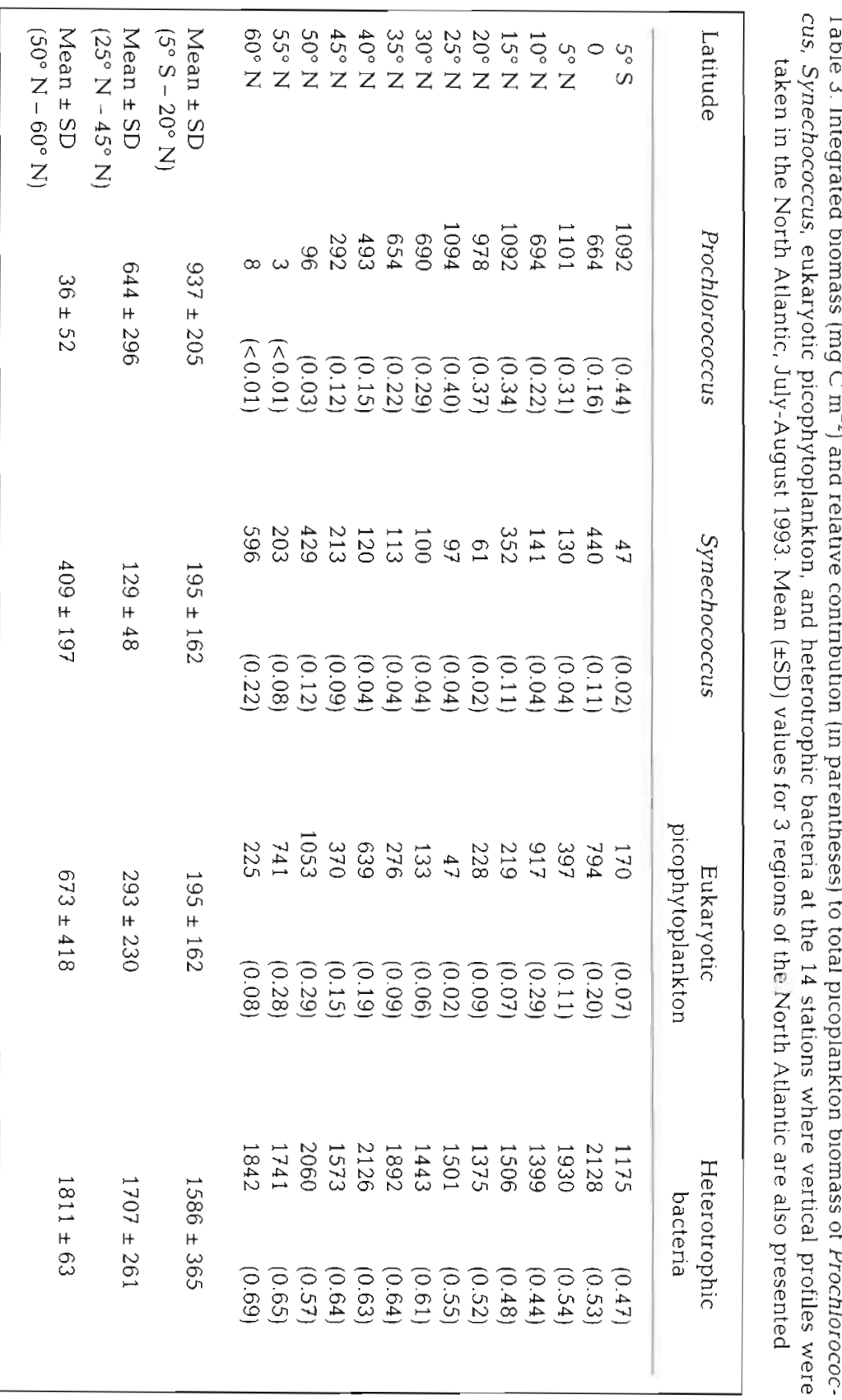


Table 4. Mean surface $( \pm S D)$ biomass $\left(\mu g \mathrm{C}^{-1}\right)$ and mean $( \pm S D)$ relative contribution of the autotrophic and heterotrophic components of total living carbon measured with flow cytometry and epifluorescence microscopy at the surface along a transect in the North Atlantic, July-August 1993

\begin{tabular}{|c|c|c|c|}
\hline & $\begin{array}{c}5^{\circ} \mathrm{S}-24^{\circ} \mathrm{N} \\
(\mathrm{N}=30)\end{array}$ & $\begin{array}{c}25^{\circ}-45^{\circ} \mathrm{N} \\
(\mathrm{N}=12)\end{array}$ & $\begin{array}{c}50^{\circ}-61^{\circ} \mathrm{N} \\
(\mathrm{N}=9)\end{array}$ \\
\hline \multicolumn{4}{|l|}{ Phytoplankton } \\
\hline \multicolumn{4}{|l|}{ Prochlorococcus } \\
\hline Biomass & $12.8 \pm 4.1$ & $3.9 \pm 2.1$ & $0.2 \pm 0.2$ \\
\hline Relative contribution & $0.30 \pm 0.06$ & $0.13 \pm 0.04$ & 0 \\
\hline \multicolumn{4}{|l|}{ Synechococcus } \\
\hline Biomass & $3.0 \pm 3.9$ & $1.1 \pm 0.7$ & $7.1 \pm 3.0$ \\
\hline Relative contribution & $0.06 \pm 0.04$ & $0.04 \pm 0.03$ & $0.05 \pm 0.03$ \\
\hline \multicolumn{4}{|l|}{ Eukaryotic picoplankton } \\
\hline Biomass & $2.0 \pm 2.9$ & $0.9 \pm 0.9$ & $11.9 \pm 7.4$ \\
\hline Relative contribution & $0.04 \pm 0.04$ & $0.03 \pm 0.02$ & $0.08 \pm 0.06$ \\
\hline \multicolumn{4}{|l|}{ Nano- and microplankton } \\
\hline Biomass & $7.1 \pm 6.3$ & $6.8 \pm 3.6$ & $52.5 \pm 20.8$ \\
\hline Relative contribution & $0.15 \pm 0.06$ & $0.22 \pm 0.05$ & $0.42 \pm 0.11$ \\
\hline \multicolumn{4}{|l|}{ Total phytoplankton } \\
\hline Biomass & $24.9 \pm 14.7$ & $12.7 \pm 5.9$ & $71.7 \pm 21.5$ \\
\hline Relative contribution & $0.54 \pm 0.05$ & $0.41 \pm 0.05$ & $0.54 \pm 0.08$ \\
\hline \multicolumn{4}{|l|}{ Heterotrophs } \\
\hline \multicolumn{4}{|l|}{ Bacteria } \\
\hline Biomass & $15.5 \pm 6.3$ & $11.8 \pm 4.3$ & $28.4 \pm 3.7$ \\
\hline Relative contribution & $0.35 \pm 0.04$ & $0.41 \pm 0.08$ & $0.19 \pm 0.08$ \\
\hline \multicolumn{4}{|l|}{ Nano- and microplankton } \\
\hline Biomass & $4.9 \pm 1.7$ & $5.4 \pm 3.0$ & $37.4 \pm 17.0$ \\
\hline Relative contribution & $0.11 \pm 0.04$ & $0.18 \pm 0.06$ & $0.27 \pm 0.08$ \\
\hline \multicolumn{4}{|l|}{ Total heterotrophs } \\
\hline Biomass & $20.4 \pm 7.5$ & $17.2 \pm 5.8$ & $64.0 \pm 17.9$ \\
\hline Relative contribution & $0.46 \pm 0.05$ & $0.59 \pm 0.05$ & $0.46 \pm 0.08$ \\
\hline Total living biomass & $45.3 \pm 21.8$ & $29.9 \pm 11.0$ & $135.6 \pm 35.1$ \\
\hline
\end{tabular}

cytometry protocol (Olson et al. 1990, Chavez et al. 1991, Campbell \& Vaulot 1993, Li 1995, Landry et al. in press). The Prochlorococcus vertical profiles south of the gyre are reminiscent of the HOT site (Campbell \& Vaulot 1993) and the equatorial Pacific (Chavez et al. 1991, Landry et al. in press). There are minor differences, namely the depth of the slight subsurface maxima we observed is well above the DCM at most stations and the absolute abundances of the profile at $15^{\circ} \mathrm{N}$ exceed those reported before (Campbell et al. 1994, Landry et al. in press). The stations in the central gyre, with their distinct deep maxima, are similar to the Sargasso Sea, particularly in the spring and summer (Olson et al. 1990). By way of comparison the HOT site recorded $20 \times 10^{6}$ cells $\mathrm{mm}^{-2}$ (Campbell et al. 1994) and the Sargasso Sea recorded $6 \times 10^{6}$ cells $\mathrm{mm}^{-2}$ (Olson et al. 1990) in comparable depths sampled. Olson et al. (1990) report finding no Prochlorococcus in North Atlantic waters with surface temperatures less than $17^{\circ} \mathrm{C}$. The apparent influence of temperature on the distribution of Prochlorococcus in our study is very marked (Fig. 5), however the presence of small populations in cold water indicates that it might not be as rigid a boundary as initially thought. Vaulot et al. (1990) reports small populations of Prochlorococcus in winter waters of the Mediterranean with surface temperatures of 12 to $14^{\circ} \mathrm{C}$ comparable to the temperatures we report for the stations at the northern end of our transect.

The work most comparable to ours is that undertaken by Li (1995) on cross (E-W) basin cruises in 1992 and 1993 through the subtropical region. Our mean $(n=5)$ profile of the picophytoplankton from the subtropical region shows good correspondence with the mean profile generated by Li (1995). Our eukaryote and Synechococcus profile (not shown) is similar to that of his fall 1993 cruise while our Prochlorococcus profile (not shown) is remarkably similar to the MayJune cruise.

Synechococcus. The average abundance we report from the tropical region (Table 1) was higher than values reported from the HOT site (max. of $6.3 \times 10^{3}$ cells $\mathrm{ml}^{-1}$; L. Campbell unpubl.), comparable to those from the Equatorial Pacific $\left(8.0 \times 10^{3}\right.$ cells $\mathrm{ml}^{-1}$, Blanchot et al. $1992 ; 2.1 \times 10^{4}$ cells $\mathrm{ml}^{-1}$ for $0 \mathrm{~m}$ only, Chavez et al. 1990). Our abundance estimates of Synechococcus at $40^{\circ}$ and $45^{\circ} \mathrm{N}$ (Table 2, Figs. $3 \& 5$ ) are lower than previous reports of Prochlorococcus abundance from the open ocean that used the high sensitivity flow 
those reported by $\mathrm{Li}$ et al. (1993) during the spring bloom (mean $=1.7$ and $1.4 \times 10^{4}$ cells $\mathrm{ml}^{-1}$ respectively) and either lower than, equal to or higher than the Sargasso Sea depending upon the year and season (Olson et al. 1990, Li et al. 1992). Contrary to the finding of Murphy \& Haugen (1985), the abundance of Synechococcus in our study was not positively correlated with temperature; highest abundances encountered were from the subarctic (Figs. 3 to 6, Tables $1 \& 4$ ). In fact, the slope of the regression of Synechococcus against temperature for the region in our study comparable to the Murphy \& Haugen (1985) study area (stations north of $36^{\circ} \mathrm{N}$ ) was negative (Synechococcus = -2466 Temperature $+55644, r^{2}=0.6$, plot not shown). The lack of consistent vertical structure in our profiles of Synechococcus throughout the water column is also contradictory to previous findings (Le Bouteiller et al. 1992, Campbell \& Vaulot 1993).

Eukaryotic picophytoplankton. These abundances are in the same range of maximum abundances reported from the Pacific by Landry et al. (in press) but higher than those reported by Chavez et al. (1990). The discrete abundances observed during this study were higher than those reported from the HOT site although the profile shape, with its subsurface maxima, is simiIar (Campbell \& Vaulot 1993). The subsurface maximum seems to be a consistent feature of this group of organisms that transgresses individual studies. The biomass ratio of 1:1 for eukaryotic picophytoplankton to heterotrophic flagellates has been used to estimate the contribution of heterotrophic flagellates to total living carbon (Campbell et al. 1994). In this study how ever, the mean ratio for surface samples was $0.4 \pm 0.5$.

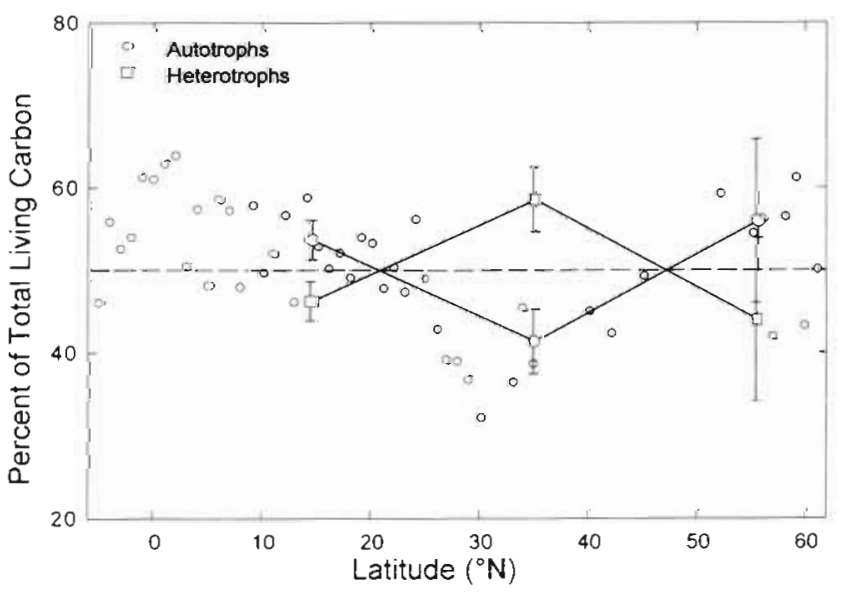

Fig. 7 Percent of total living carbon associated with autotrophic organisms in surface waters at 51 stations in the North Atlantic, July to August 1993. Symbols connected by lines are means (error bars = SD) of the autotrophic and heterotrophic components of the total living carbon for the tropical, subtropical and subarctic regions
With depth and the attendant increase in eukaryotic picophytoplankton abundance (Fig. 3) this ratio may approach 1 The correlation coefficient between the biomass of these 2 parameters was 0.6 ( $p \ll 0.01$ ).

Nano- and microplankton. The concentrations of nano-and microplankton from this study at the equator were 17.4 and $6.7 \mu \mathrm{g} \mathrm{C} \mathrm{l^{-1 }}$ for autotrophs and heterotrophs respectively (Fig. 6); Chavez et al. (1991)

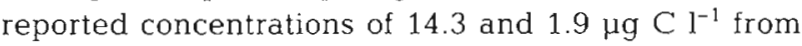
the surface at the equator on $140^{\circ} \mathrm{W}$ in the Pacific Ocean. One of the few studies that used EFM to estimate the biomass of larger organisms from a subtropical region with which we can compare our enumerations is that of Fuhrman et al. (1989). At comparable

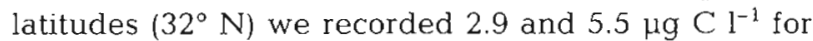
autotrophs and heterotrophs respectively compared to 2.1 and $1.4 \mu \mathrm{g} \mathrm{Cl}^{-1}$ for PNAN and HNAN respectively from the Sargasso Sea. Sieracki et al. (1993) estimated autotrophic nano- and microplankton biomass in the upper $30 \mathrm{~m}$ at $46^{\circ} \mathrm{N}, 18^{\circ} \mathrm{W}$ to be from 48.1 to $54.8 \mu \mathrm{g} \mathrm{C}$ $1^{-1}$ during the spring bloom in May of 1989 while the heterotrophic component ranged between 36.2 and $46.3 \mu \mathrm{g} \mathrm{C} \mathrm{l}^{-1}$. Estimates from 45 and $48^{\circ} \mathrm{N}$ in the North Atlantic in 1993 (present study) were considerably lower, 13.7 and $15.0 \mu \mathrm{g} \mathrm{Cl} \mathrm{l}^{-1}$ for the autotrophs and 8.0 and $13.2 \mu \mathrm{g} \mathrm{C} \mathrm{l}^{-1}$ for the heterotrophs (Fig. 6). The magnitude of the contribution of nano- and microplankton to total living carbon biomass is large enough (Table 4) that to obtain accurate estimates of the ratio of heterotrophs to autotrophs one must include these components.

\section{Trophic relationships}

Partitioning total living carbon for 3 regions in the North Atlantic into autotrophic and heterotrophic components resulted in a significantly higher proportion of heterotrophic biomass in the subtropical regions than in either the tropical or subarctic region (Fig. 7 , Table 4) using the particular suite of conversions we employed. Both the tropical and subarctic living biomass are $46 \%$ heterotrophic while the subtropical region is $59 \%$ heterotrophic biomass (Table 4 ). This finding confirms the existence of large geographical regions with as much or more heterotrophic than autotrophic biomass, posited by other investigators (Dortch \& Packard 1989, Fuhrman et al. 1989, Cho \& Azam 1990, Herndl 1991, Li et al. 1992, 1993). However, the degree to which this biomass ratio is skewed in the direction of the heterotrophs is less than suggested for some other areas (Fuhrman et al. 1988, Cho \& Azam 1990). In terms of the chlorophyll, the highest proportions of total living biomass attributable to heterotrophs in our study are found in the most olig- 
otrophic regions (Fig. 8). This is similar to the relationship described by Cho \& Azam (1990) for the North Pacific; however, the maximum BOC:Cp (bacterial organic carbon:phytoplankton carbon) that emanates from our study, where we used the FC and EFM generated biomass estimates, 1.5 , is much lower than that reported for the North Pacific (maximum $>8$ ). By way of comparison, Campbell et al. (1994) reported a ratio of 0.82 from the HOT site. If we had used our chlorophyll concentrations to generate the autotrophic biomass by applying the same C:chl ratio as used by Cho \& Azam (1990) (50), the resultant plot (not shown) looks similar to the one they generated, with maximal values of $\mathrm{BOC}: \mathrm{Cp}$ in excess of 6 .

There are numerous published volume to carbon conversions that can be invoked to estimate the concentration of heterotrophic and autotrophic biomass. Obviously the degree of heterotrophy characteristic of a region will depend upon which of these factors one chooses. If we examine the results when extremes of volume to carbon conversions are applied, we generate a range of values for the degree of heterotrophy for the 3 regions. For the autotrophic extreme we will use the conversions stated in the 'Materials and methods', as they are amongst the highest values published, with the heterotrophic bacterial conversion of $10 \mathrm{fg} \mathrm{C} \mathrm{cell}^{-1}$ (Christian \& Karl 1994). This combination produces relative proportions of the total living carbon attributable to heterotrophs of 35,48 and $41 \%$ for the tropical, subtropical and subarctic regions respectively. For the heterotrophic extreme we will use the carbon to chlorophyll ratio of 50 and the heterotrophic bacterial conversion of $20 \mathrm{fg} \mathrm{C}$ cell $^{-1}$ (Lee \& Fuhrman 1987). This results in heterotrophic percentages of 73,83 and $62 \%$ for the same 3 regions, respectively. While clearly there is no single solution to this equation we can unequivocally state that the subtropical region/oligotrophic gyre is more heterotrophic than the regions bounding it and that the heterotrophic biomass of this area is at least equal to the autotrophic biomass and probably exceeds it.

Carbon to chlorophyll ratios. The carbon to chlorophyll ratios we generated from direct flow cytometric and microscopic analysis covaried with chlorophyll concentrations; highest ratios were found at lowest chlorophyll concentrations $\left[\log _{10}(\mathrm{C}: \mathrm{chl})=1.92-\right.$ $0.31 \log _{10}(\mathrm{chl}), \mathrm{r}^{2}=0.6$, correction factor $=1.13 ;$ Fig. 9a] The use of a constant carbon to chlorophyll ratio, such as 50 (Cho \& Azam 1990, Christian \& Karl 1994) or 30 (Herndl 1991), across the North Atlantic basin would result in a gross underestimation of the autotrophic biomass at low chlorophyll concentrations, such as those we report from the subtropical region (see previous section). The carbon to chlorophyll ratios we calculate are high $(172 \pm 51,180 \pm 39$ and $82 \pm 42$ for the tropical, subtropical and subarctic regions respectively), however, Campbell et al. (1994) reported a surface mixed layer ratio of 128 for the HOT site. Ratios such as ours, estimated solely from surface values, should be higher than one calculated on the basis of samples from throughout the euphotic zone. However, both of these estimates of autotrophic biomass use generous volume to carbon conversions. We have chosen to use these conversions to facilitate comparison with as many other studies as possible, however we recognize that the use of other conversions (Chavez et al. in press) might affect the outcome of these calculations. Irrespective of the volume to carbon conversion used, surface carbon to chlorophyll ratios vary systematically across the North Atlantic Ocean and carbon to chlorophyll ratios for most of the transect are well in excess of 50 .

The ratio is often adjusted to account for vertical differences in the per cell chlorophyll content (Li et al. 1992), but areal differences have not commonly been accounted for. Campbell et al. (1994) found that their conclusions were unaltered if they used biovolume instead of estimated carbon as the parameter of choice. An independent estimate of carbon to chlorophyll ratios is found in the fluorescence per cell measured by FC in our surface samples. Red fluorescence per Prochlorococcus and Synechococcus cell is indeed lowest in the most oligotrophic region and highest in the most eutrophic region (Fig. 9b). If we make the assumption that cell size and therefore carbon content

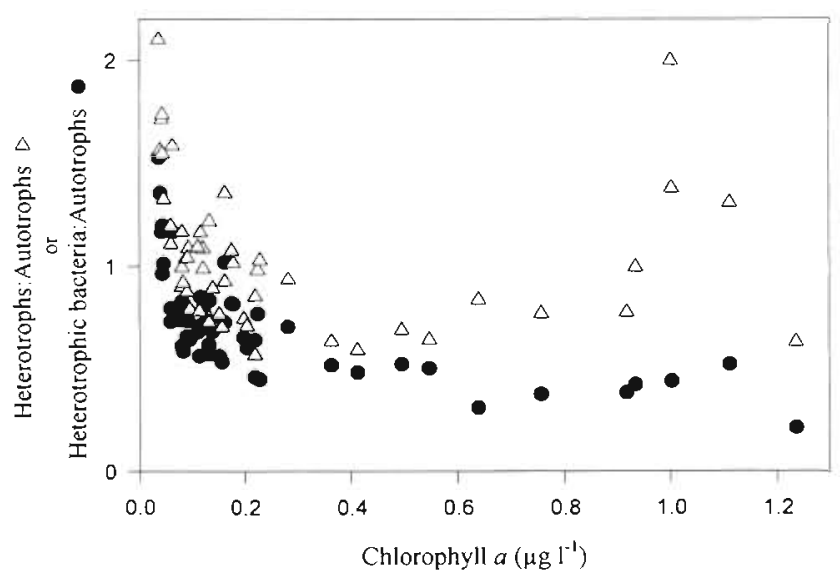

Fig. 8. Ratio of heterotrophic bacterial or total heterotrophic (heterotrophic bacteria and heterotrophic nano- and microplankton) biomass to autotrophic biomass plotted against chlorophyll for 51 surface samples from the North Atlantic, July to August 1993. The high values of Heterotrophs: Autotrophs at the high concentrations of chlorophyll reflect the high abundance of Solenicola setigera, a heterotrophic flagellate that forms a symbiotic relationship with the centric diatom Leptocylindrus mediterraneus, that was abundant in the subarctic region 


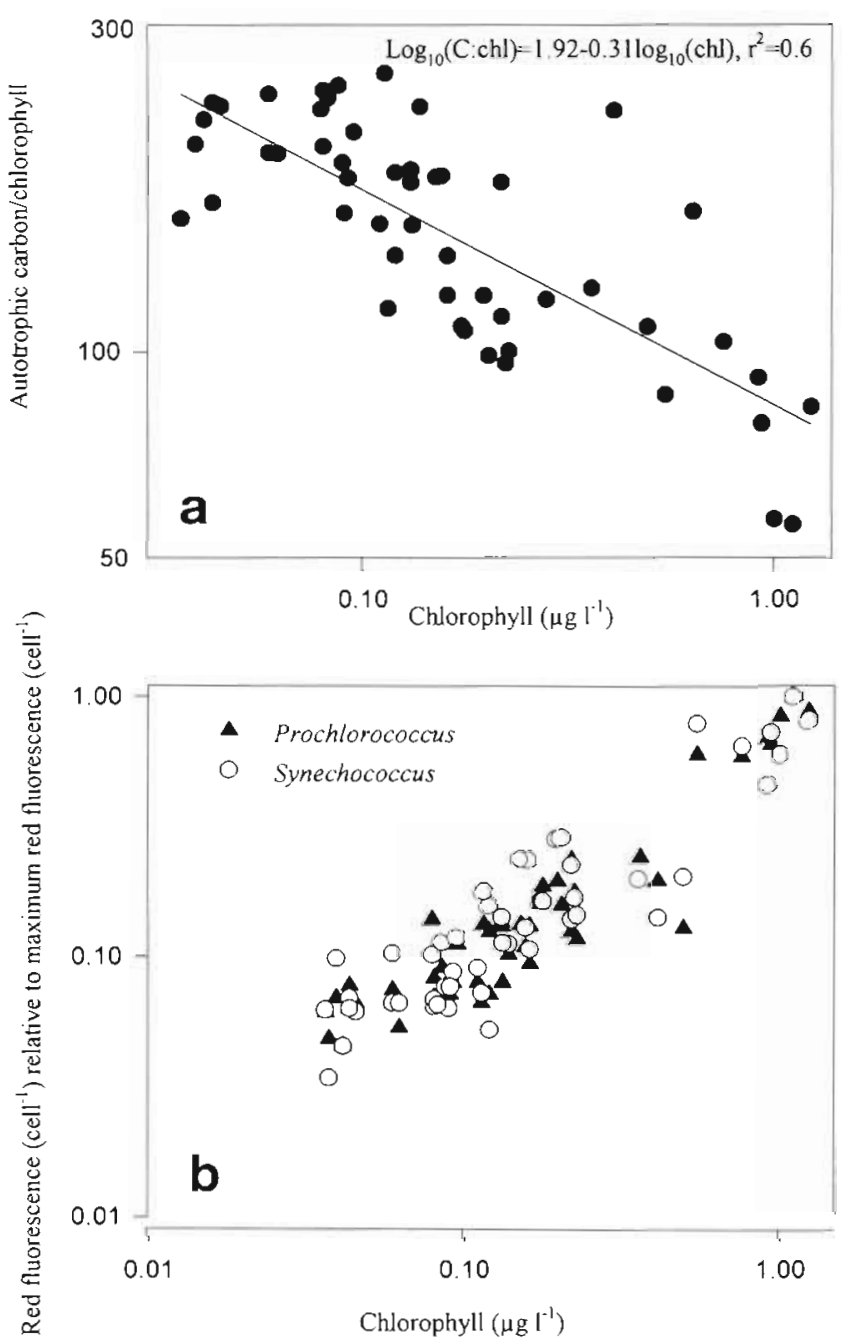

Fig 9. (a) Ratio of phytoplankton carbon, derived from a combination of FC and EFM, to chlorophyll plotted against chlorophyll. (b) Surface red fluorescence per Synechococcus and prochlorococcus cell (normalized to the maximum surface red fluorescence per cell recorded on the cruise) vs chlorophyll concentration for 51 surface samples collected in the North Atlantic, summer 1993. Fluorescence measurements were normalized to $0.57 \mu \mathrm{m}$ yellow-green Fluoresbrite beads

of these 2 groups is invariant from region to region, then a lower cell fluorescence translates into a higher carbon to chlorphyll ratio in the oligotrophic region. Cellular fluorescence measurements of Prochlorococcus and Synechococcus at the HOT station Aloha showed a seasonal trend (Winn et al. 1995). This was interpreted as a signal of changing cellular chlorophyll concentration, in this case as a response to photoadaptation and/or changing nutrient concentrations. Experimental work with cultures, where the carbon was determined with a CHN analyzer, has also demonstrated higher carbon to chlorophyll ratios under the condition of nitrogen deficiency (Riemann et al. 1989).
These 3 independent approaches to looking at the changes in carbon to chlorophyll ratios with respect to trophicity all come to the same conclusion, namely that the ratio is much higher in the most oligotrophic region of the North Atlantic.

Depth relationships. We were concerned that the estimates of the proportion of total living biomass attributable to heterotrophs might be an artifact of our considering only surface samples. The biomass of the tropical and subtropical regions is dominated by the sum of Prochlorococcus and heterotrophic bacteria ( 0.65 and 0.54 of the total living carbon respectively; Table 4). It is the change in the biomass of these 2 organisms that in large part accounts for the shift from an autotrophic tropical region to a heterotrophic subtropical region in the surface waters. We have shown that the proportion of the total small prokaryote biomass composed of Prochlorococcus remains nearly constant within the upper $100 \mathrm{~m}$ of the tropical and subtropical water column. Although increases in the biomass of specific organisms such as eukaryotic picophytoplankton can and do occur with depth (Fig. 3), their contribution to the total integrated picoplankton biomass in the subtropical region decreases relative to both the tropical and subarctic regions (Fig. 4, Table 3). Fuhrman et al. (1989) reported an increase in microscopically derived heterotrophic biomass with depth $(10$ to $150 \mathrm{~m}$ ) for 2 of the 3 depth profiles for which data is presented. We need actual EFM counts from depth with which to combine the FC estimates before we can unequivocally state that the surface derived ratios of heterotrophic to autotrophic biomass are valid throughout the upper $100 \mathrm{~m}$ but all evidence indicates that this is the case.

Implications. Having broad geographical areas of an ocean basin dominated by heterotrophic biomass necessarily entails changing either the production or loss terms in the steady state model of the microbial foodweb. A comprehensive discussion of many of these possibilities appears in Fuhrman (1992). Low bacterivore populations, inefficient feeding by bacterivores, disparate turnover rates for the 2 fractions, discrimination against heterotrophs by grazers, increased DOM release by phytoplankton and the photochemical reduction of refractory allochthonous DOM are the potential factors that might help explain how the imbalance is maintained (Fuhrman et al. 1989, Cho \& Azam 1990, Fuhrman 1992). In oligotrophic lakes heterotrophic domination of total living carbon is supported by the allochthonous import of DOM from littoral macrophytic and periphytic production (Coveney \& Wetzel 1995).

Our data indicates that the protozoan heterotrophic biomass actually increases in both absolute and relative terms from the tropical to subtropical zone 
(Table 4, Fig. 6); it seems unlikely therefore that total grazing pressure decreases in oligotrophic regions. Although comprehensive information is available on the identity of grazers and their community grazing rates from tropical regions (Landry et al. 1995, Vørs et al. 1995), neither the specific identity nor the grazing potential of the oligotrophic het erotrophic population is known. There is a shift upward in the size spectrum of both the heterotrophic and autotrophic organisms in the subtropical region over those of the tropical region (Fig. 10). The heterotrophic protists may be responding to the increase in prey size (Hansen et al. 1994) and an actual decrease in grazing pressure on the picoplankton fraction may be occurring.

Size of organisms. The chlorophyll size fractionation data (data not shown) supports the increase in the assemblage equivalent spherical diameter (ESD) that we document with FC and EFM. The tropical station $\left(2^{\circ} \mathrm{N}\right)$ in Fig. 10 had only $16 \%$ of the total chlorophyll retained by the $1 \mu \mathrm{m}$ filter while the subtropical station $\left(30^{\circ} \mathrm{N}\right)$ had $39 \%$ of total chlorophyll retained on the $1 \mu \mathrm{m}$ filter. Both of these values, however, are below the $1: 1$ ratio of chlorophyll larger and smaller than $1 \mu \mathrm{m}$, in the range of what is described as the typical condition for oligotrophic waters (Le Bouteillier et al. 1992). Li (1994) reported that most of the primary productivity in the oligotrophic region of the North Atlantic can be attributed to a group that he labeled the LEUC (large eukaryotes). LEUCS are characterized by being retained on a $1 \mu \mathrm{m}$ pore sized filter but largely passing through a $2 \mu \mathrm{m}$ filter. Furthermore, the vast majority of the biomass of the ultraplankton $(<5 \mu \mathrm{m})$, determined by the forward angle light scatter of the flow cytometry signal, from this same region was attributable to the eukaryotes ( $\mathrm{Li}$ 1995). These 3 independent measures of size structure all indicate that the subtropical region assemblage is larger than that of the tropical region. Both of these assemblages are, of course, smaller than that of the subarctic region during the time we sampled, producing a gradient of assemblage sizes ranging from small to large from the tropical region northward.

\section{Bacteria to chlorophyll ratios}

It has been assumed that bacterial abundance and biomass covary with the trophic status of the marine environment (Bird \& Kalff 1984, Cole et al. 1988) as
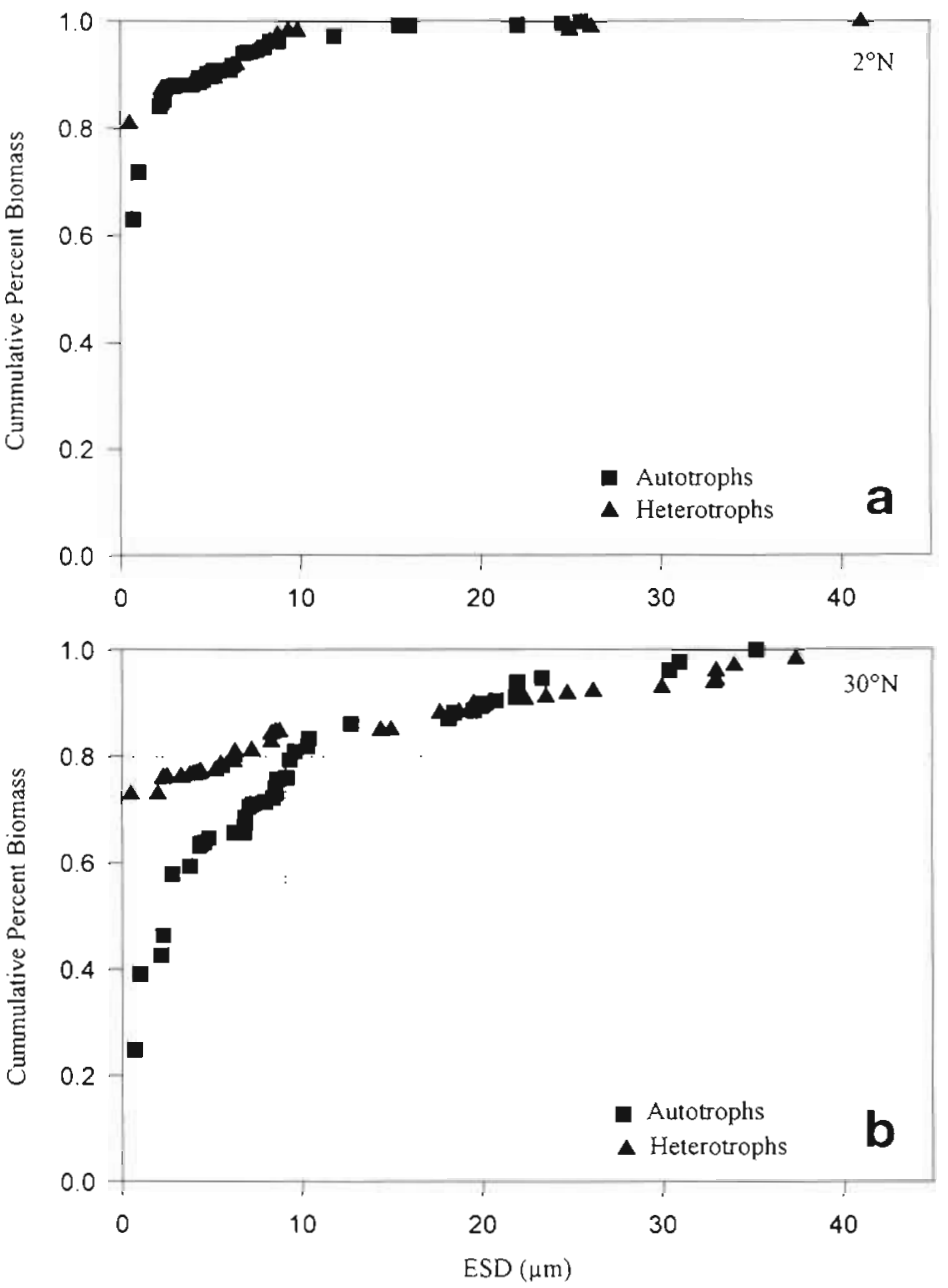

Fig. 10. Cumulative percent biomass plotted as a function of increasing equivalent spherical diameter (ESD) of autotrophs and heterotrophs for (a) a station from the tropical region and (b) a station from the subtropical region of the North Atlantic, July to August 1993

defined by chlorophyll concentrations. Cho \& Azam (1990) found that this relationship held for the mesotrophic and eutrophic waters of the North Pacific but broke down for the most oligotrophic regions $\left(<0.5 \mathrm{\mu g}\right.$ chlorophyll $\mathrm{l}^{-1}$ ) of the North Pacific. They report that the slope of the oligotrophic bacterial abundance to chlorophyll ratio was not statistically different than 0 , i.e. below $0.5 \mu \mathrm{g} \mathrm{l}^{-1}$ of chlorophyll, chlorophyll continues to decrease, but bacterial numbers stabilize. We obtained a different relationship between bacterial abundance and chlorophyll [Fig. 11a; $\log _{10}$ (bacterial abundance $)=6.17+0.36\left(\log _{10}\right.$ chlorophyll $), r^{2}=0.73$, correction factor $=1.01$ ] than that generated in other studies (Bird \& Kalff 1984, Cole et al. 1988, Cho \& Azam 1990, Li et al. 1992). A single regression sufficed for the whole range of chlorophyll concentrations we measured $\left(0.036\right.$ to $1.235 \mu \mathrm{g}$ chlorophyll $\left.\mathrm{l}^{-1}\right)$. We inves- 

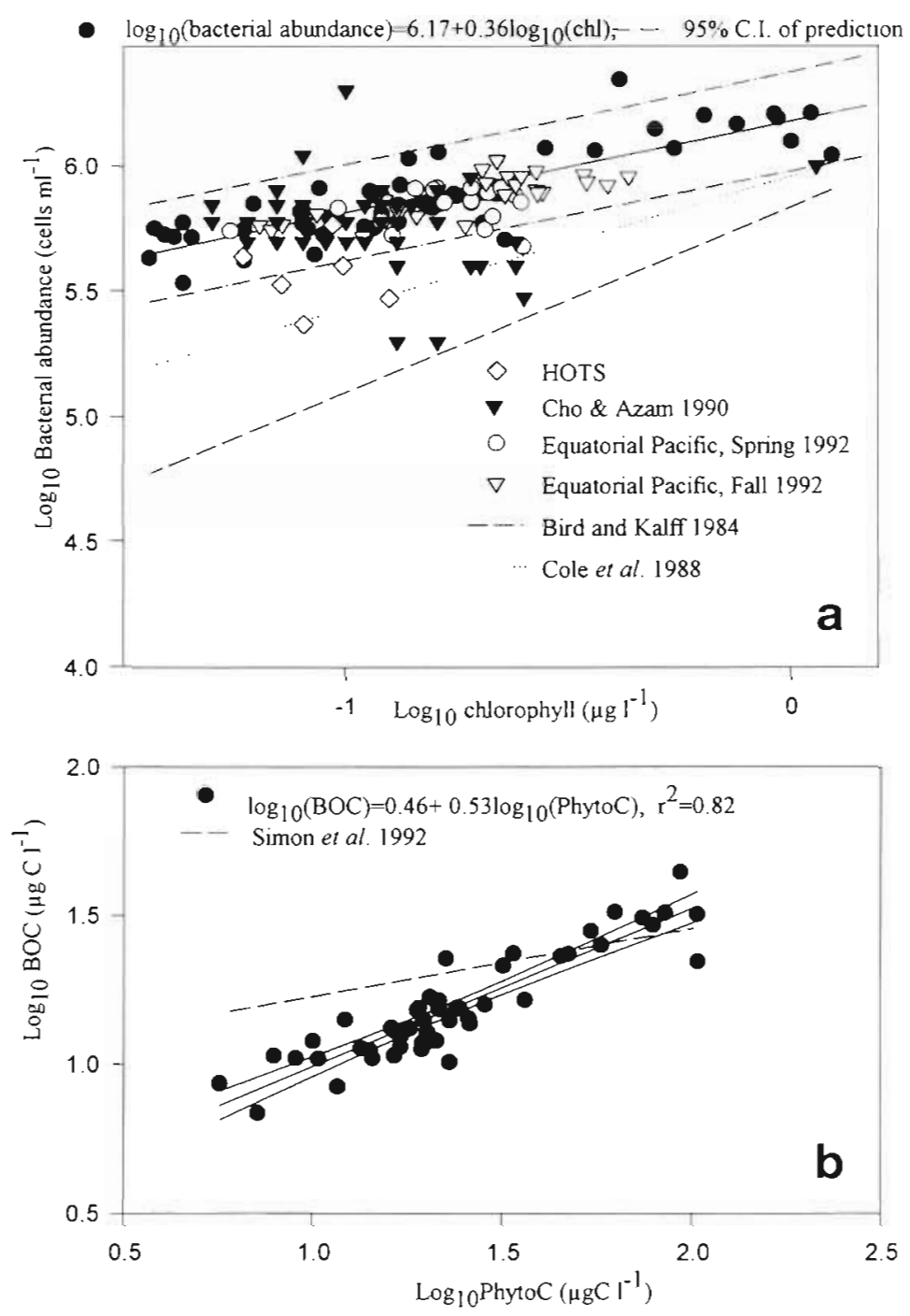

Fig. 11. (a) $\log _{10}$ bacterial abundance plotted against $\log _{10}$ chlorophyll concentration with $95 \%$ confidence intervals of prediction for surface samples from the North Atlantic, July to August 1993, the equatorial Pacific and the HOT site, all of which were analysed with dual beam FC. The regressions from Bird \& Kalff (1984) and Cole et al. (1988) and the data from Cho \& Azam (1991) are also plotted. (b) Log 10 heterotrophic organic biomass (BOC) plotted against $\log _{10}$ phytoplankton organic carbon (PhytoC). The regression line from Simon et al. (1992) is also plotted

across the broad range of trophic conditions in the marine environment as proposed by Bird \& Kalff (1984) and Cole et al. (1988). The surface chlorophyll and bacterial concentrations obtained by Landry et al. (in press) from the equatorial Pacific fit well within the $95 \%$ confidence limits of prediction we generated from the Atlantic, however 4 of the 6 points obtained from the HOT site do not (Fig. 11a). More data, particularly from eutrophic regions, is needed to ascertain whether or not the relationship between chlorophyll and bacterial abundance we generated is applicable to all regions of the world ocean. Intuitively the data obtained from flow cytometry should lie below the data generated via microscopy if the problem of enumerating Prochlorococcus as heterotrophic bacteria is a major one, i.e. the abundance estimates of heterotrophic bacteria generated by epifluorescence microscopy should be higher than those generated by flow cytometry. Most of the heterotrophic bacterial abundance estimates derived from flow cytometry used in Fig. 11a lie above the regressions of Bird \& Kalff (1984) and Cole et al. (1988), indicating higher heterotrophic bacterial abundances per unit chlorophyll than previously thought. The absence of data from oligotrophic regions in these 2 studies may partially explain this discrepancy although the data of Li et al. (1992) from the Sargasso Sea lies directly on the Cole et al. (1988) regression. We use only our surface heterotrophic bacterial abundances and chlorophyll in this regression whereas the review by Cole et al. (1988) used photic zone values, and Bird \& Kalff (1984) used predominantly (69\%) $1 \mathrm{~m}$ values. Some of the differences in the respective regression equations may emanate from using samples from throughout the euphotic zone. Other artifacts associated with the microscopical determination of bac-

tigated whether the difference in the regression we calculated for the bacterial abundance to chlorophyll ratio compared to those generated by others could be attributed to some of the methodological differences that set our study apart.

Adding the Prochlorococcus abundance to the heterotrophic bacterial abundance did not change the slope (plot not shown). Plotting additional points generated by dual beam flow cytometry from other regions should give an indication of whether a single regression is going to suffice to predict bacterial populations terial abundance such as long term storage of preserved samples prior to processing (Turley \& Hughes 1992) or the use of DAPI instead of acridine orange to image bacteria on filters (Suzuki et al. 1993) may in part explain our finding higher bacterial abundances for a given chlorophyll concentration. We also undertook comparison of our heterotrophic bacterial (BOC) to phytoplankton (PhytoC) carbon regression $\left[\log _{10}(\right.$ bacterial abundance $)=5.16+0.53\left(\log _{10}\right.$ phytoplankton carbon), $r^{2}=0.83$, correction factor $=1.01$ ] with that of Simon et al. (1992) (Fig. 11b). The slope of 
their regression is low, a condition that they attributed to using size related carbon content for their bacterial biomass estimate. We use an invariant volume to carbon conversion factor for heterotrophic bacteria so this might well account for some of the difference. However, they also used the original carbon to chlorophyll ratios in the publications from which the data comes to calculate PhytoC in the majority of their marine data and this would also account for the low slope of the line.

\section{CONCLUSIONS}

(1) Total living biomass of the North Atlantic subtropical region $\left(25^{\circ}\right.$ to $\left.45^{\circ} \mathrm{N}\right)$ along the $20^{\circ} \mathrm{W}$ meridian during July-August 1993 was dominated by heterotrophic biomass, while autotrophic biomass dominated tropical and subarctic regions. As autotrophic biomass and chlorophyll decrease this ratio increases. Although the degree to which the heterotrophic biomass component outweighed the autotrophic component was less than reported by previous studies from other regions, heterotrophic domination was apparent in the North Atlantic during the summer of 1993 and may be a universal feature of the central gyres of the major ocean basins.

(2) Carbon to chlorophyll ratios varied spatially with the highest ratios found in the most oligotrophic region. Due to this variation across trophic regimes, the use of a single carbon to chlorophyll ratio to predict autotrophic biomass seriously underestimates this component in the most oligotrophic regions. The diversity of volume to carbon conversions compounds the calculation of carbon to chlorophyll ratios and partitioning of the total living biomass into autotrophic and heterotrophic components. However, it is evident that the direct measurement of biovolume using both dual beam flow cytometry and epifluorescence microscopy is necessary to get an accurate assessment of the heterotrophic and autotrophic components of total living biomass.

(3) Heterotrophic bacterial abundances generated via flow cytometry from both the Pacific and Atlantic Oceans are generally higher per unit chlorophyll than those indicated from previous studies. The basin-wide regression of surface heterotrophic bacterial abundances or biomass against surface chlorophyll or phytoplankton we generated for the North Atlantic are robust, however some other FC dual beam data show more scatter.

(4) Prochlorococcus concentrations and distributions throughout the upper water column in the tropical region are reminiscent of those found at the equator and the HOT site in the Pacific; those of the subtropical region are similar to those reported from the Sargasso Sea.

(5) Nano- and microplankton, both heterotrophic and autotrophic, contribute more to the total biomass in the subtropical region than in the tropical region. This component contributed most to the biomass in the subarctic region. There is an increase in the size of the assemblages from the tropical to the subarctic regions.

Acknowledgements. We thank the crew and officers of the NOAA ship 'Malcolm Baldrige'. M. Sanderson and S. Service assisted in collecting the samples and $\mathrm{H}$. Nolla analysed the FC samples. S. Service, D. Hansell, M. Coveney and 3 anonymous reviewers provided helpful comments. This study was supported by NOAA award NA36GP0269 to F.C.

\section{LITERATURE CITED}

Banse K (1977) Determining the carbon-to-chlorophyll ratio of natural phytoplankton. Mar Biol 41:199-212

Baskerville GL (1972) Use of logarithmic regression in the estimation of plant biomass. Can J Forest Res 2:49-53

Bird DF, Kalff J (1984) Empirical relationships between bacterial abundance and chlorophyll concentration in fresh and marine waters. Can J Fish Aquat Sci 41:1015-1023

Blanchot J, Rodier M, Le Bouteiller A (1992) Effect of El Niño southern oscillation events on the distribution and abundance of phytoplankton in the western Pacific tropical ocean along $165^{\circ} \mathrm{E}$. J Plankton Res 14:137-156

Buck KR, Ertebjerg G, Larsen J, Thomsen H (1992) Biomass and abundance of pelagic cyanobacteria and protists from the transition area between the Baltic Sea and the North Sea, July 1990. In: Bjornestad E, Hagerman L, Jensen K (eds) Proc 12th European Marine Biologists Symposium. Olsen and Olsen, Fredensborg, p 35-42

Campbell L, Nolla HA, Vaulot D (1994) The importance of Prochlorococcus to community structure in the central north Pacific. Limnol Oceanogr 39:954-961

Campbell L, Vaulot D (1993) Photosynthetic picoplankton community structure in the subtropical north Pacific Ocean near Hawaii (station ALOHA). Deep Sea Res 40: 2043-2060

Chavez FP, Buck KR, Barber RT (1990) Phytoplankton taxa in relation to primary production in the equatorial Pacific. Deep Sea Res 37:1733-1752

Chavez FP, Buck KR, Coale KH, Martin JH, Ditullio GR, Welschmeyer NA, Jacobson AC, Barber RT (1991) Growth rates, grazing, sinking and iron limitation of equatorial Pacific phytoplankton. Limnol Oceanogr 36: $1816-1833$

Chavez FP, Buck KR, Service SK, Newton J, Barber RT (in press) Phytoplankton variability in the central and eastern tropical Pacific. Deep Sea Res

Cho BC, Azam F (1990) Biogeochemical significance of bacterial biomass in the ocean's euphotic zone. Mar Ecol Prog Ser 63:253-259

Christian JR, Karl DM (1994) Microbial community structure at the U.S. Joint Global Ocean Flux Study Station Aloha: inverse methods for estimating biochemical indicator ratios. J Geophys Res 99:14269-14276

Cole JJ, Findlay S, Pace ML (1988) Bacterial production in fresh and saltwater ecosystems: a cross-system overview. Mar Ecol Prog Ser 43:1-10 
Coveney MF, Wetzel RG (1995) Biomass, production, and specific growth rate of bacterioplankton and coupling to phytoplankton in an oligotrophic lake. Limnol Oceanogr 40:1187-1200

Dortch Q, Packard TT (1989) Differences in biomass structure between oligotrophic and eutrophic marine ecosytems. Deep Sea Res 36:223-240

Eppley RW, Reid FMH, Strickland JDH (1970) Estimates of phytoplankton crop size, growth rates and primary production. Bull Scripps Inst Oceanogr 17:33-42

Fuhrman J (1992) Bacterioplankton roles in cycling of organic matter: the microbial food web. In: Falkowski PG, Woodhead AD (eds) Primary productivity and biogeochemical cycles in the sea. Plenum Press, New York, p 361-383

Fuhrman JA, Sleeter TD, Carlson CA, Proctor LM (1989) Dominance of bacterial biomass in the Sargasso Sea and its ecological implications. Mar Ecol Prog Ser 57:207-217

Hansen B, Bjornsen PK, Hansen PJ (1994) The size ratio between planktonic predators and their prey. Limnol Oceanogr 39:395-403

Herndl GJ (1991) Microbial biomass dynamics along a trophic gradient at the Atlantic barrier reef off Belize (Central America). PSZN I: Mar Ecol 12:41-51

Holm-Hansen $O$, Lorenzen CJ, Holmes R, Strickland JD (1965) Fluorometric determination of chlorophyll. J Cons Int Explor Mer 30:3-15

Karl DM, Letelier R, Hebel DV, Bird DF, Winn D (1992) Trichodesmium blooms and new nitrogen in the north Pacific gyre. In: Carpenter EJ, Capone DG, Reuter JG (eds) Marine pelagic cyanobacteria: Trichodesmium and other diazotrophs. Kluwer Academic Publishers, Boston, p 219-227

Landry MR, Constantinou J, Kirshtein J (1995) Microzooplankton grazing in the central equatorial Pacific during February and August 1992. Deep Sea Res 42:657-672

Landry MR, Kirshtein J, Constantinou J (in press) Abundances and distributions of picoplankton populations in the central equatorial Pacific from $12^{\circ} \mathrm{N}$ to $12^{\circ} \mathrm{S}, 140^{\circ} \mathrm{W}$. Deep Sea Res

Le Bouteiller A, Blanchot J, Rodier M (1992) Size distribution patterns of phytoplankton in the western Pacific: towards a generalization for the tropical open ocean. Deep Sea Res 39:805-823

Lee S, Fuhrman JA (1987) Relationships between biovolume and biomass of naturally derived marine bacterioplankton. Appl Environ Microbiol 53:1298-1303

Li WKW (1994) Primary production of prochlorophytes, cyanobacteria and eucaryotic ultraphytoplankton: measurements from flow cytometric sorting. Limnol Oceanogr 39: $169-175$

Li WKW (1995) Composition of ultraphytoplankton in the central North Atlantic. Mar Ecol Prog Ser 122:1-8

Responsible Subject Editor: J. A. Fuhrman, Los Angeles, Calitornia, USA
Li WKW, Dickie PM, Harrison WG, Irwin BD (1993) Biomass and production of bacteria and phytoplankton during the spring bloom in the western North Atlantic Ocean. Deep Sea Res 40:307-327

Li WKW, Dickie PM, Irwin BD, Wood AM (1992) Biomass of bacteria, cyanobacteria, prochlorophytes and photosynthetic eukaryotes in the Sargasso Sea. Deep Sea Res 39 . $501-519$

Monger BM, Landry MR (1993) Flow cytometric analysis of marine bacteria with Hoechst 33342. Appl Environ Microbiol 59.905-911

Murphy LS, Haugen EM (1985) The distribution and abundance of phototrophic ultraplankton in the North Atlantic. Limnol Oceanogr 30:47-58

Olson RJ, Chisholm SW, Zettler ER, Altabet MA, Dusenberry JA (1990) Spatial and temporal distributions of prochlorophyte picoplankton in the North Atlantic Ocean. Deep Sea Res 37:1033-1051

Riemann B, Simonsen P, Stensgaard L (1989) The carbon and chlorophyll content of phytoplankton from various nutrient regimes. J Plankton Res 11:1037-1045

Sieracki ME, Verity PG, Stoecker DK (1993) Plankton community response to sequential silicate and nitrate depletion during the 1989 North Atlantic spring bloom. Deep Sea Res 40:213-225

Simon M, Cho BC, Azam F (1992) Significance of bacterial biomass in lakes and the ocean: comparison to phytoplankton biomass and biogeochemical implications. Mar Ecol Prog Ser 86:103-110

Sprugel DG (1983) Correcting for bias in log-transformed allometric equations. Ecology 64:209-210

Suzuki MT, Sherr EB, Sherr BF (1993) DAPI direct counting underestimates bacterial abundances and average cell size compared to AO direct counting. Limnol Oceanogr 38:1566-1570

Taylor FJR (1982) Symbioses in marine microplankton. Ann Inst Oceanogr 58:61-90

Turley CM, Hughes DJ (1992) Effects of storage on direct estimates of bacterial numbers of preserved seawater samples. Deep Sea Res 39:375-394

Vaulot D, Partensky F, Neveux J, Mantoura RFC, Lllewellyn CA (1990) Winter presence of prochlorophytes in surface waters of the northwestern Mediterranean Sea. Limnol Oceanogr 35:1156-1164

Vørs N, Buck KR, Chavez FP, Eikrem W, Hansen LE, Østergaard JB, Thomsen HA (1995) Nanoplankton of the equatorial Pacific with emphasis on the heterotrophic protists. Deep Sea Res 42:585-602

Winn CD, Campbell L, Christian JR, Letelier RM, Hebel DV, Dore JE, Fujieki L, Karl DM (1995) Seasonal variability in the phytoplankton community of the North Pacific subtropical gyre. Global Biogeochem Cycles 9:605-620

Manuscript first received: October 25, 1995

Revised version accepted: March 21, 1996 